\title{
1 Investigation of extensive green roof outdoor spatio-temporal thermal 2 performance during summer in a subtropical monsoon climate
}

5 Haiwei YIN* (Corresponding author)

6 School of Architecture and Urban Planning, Nanjing University, No. 22, Hankou Road, 210093, Nanjing, China

$7 \quad$ Email: yinhaiwei@nju.edu.cn

8 Phone: +86-13814080316; Fax: +86-25-83316892

10 Fanhua KONG

11 International Institute for Earth System Science (ESSI), Nanjing University, No. 163, Xianlin Ave, 210023,

12 Nanjing, China;

13 E-mail: fanhuakong@163.com

14 Phone: +86-25-89681033; Fax: +86-25-83316892

Iryna DRONOVA

17 Department of Landscape Architecture and Environmental Planning, University of California at Berkeley,

18 Berkeley, CA 94720, United States

19 Email: idronova@berkeley.edu

21 Ariane MIDDEL

22 School of Arts, Media and Engineering, School of Computing, Informatics, and Decision Systems Engineering,

23 Arizona State University, Tempe, AZ 85281

24 Email: $\underline{\text { amiddel@asu.edu }}$

26 Philip JAMES

27 School of Environment and Life Sciences, University of Salford, Salford, M5 4WT, UK

28 Email: P.James@salford.ac.uk 

performance during summer in a subtropical monsoon climate

\section{Abstract:}

The thermal performance of green roofs is usually site-specific and changes temporally. Hence, thermal performance evaluation is necessary to optimize green roof design and its cooling effect. In this paper, we evaluated the outdoor spatio-temporal performance of a full-scale extensive green roof (EGR) in Nanjing, China throughout a summer at three heights $(30,60$ and $120 \mathrm{~cm})$. We found the EGR exhibited an overall slight diurnal cooling effect at all three heights $\left(-0.09,-0.23\right.$, and $-0.09{ }^{\circ} \mathrm{C}$, respectively), but there was an obvious warming effect at a couple of specific hours during daytime. Especially on sunny days, the maximum warming effect at all three heights was $1.59,0.59$, and $0.38^{\circ} \mathrm{C}$, respectively. During the night, the EGR had a pronounced cooling effect of $-0.63,-0.40$, and $-0.15^{\circ} \mathrm{C}$, respectively. Among the weather scenarios, sunny days had the highest impact on the EGR's thermal performance, while effects were less pronounced on cloudy and rainy days. Tthe average range of hourly air temperature difference at $30 \mathrm{~cm}$ between EGR and a bare roof on selected days was 4.02 (sunny), 2.67 (cloudy), and $0.74^{\circ} \mathrm{C}$ (rainy). The results of multiple-regression analyses showed strong and significant correlations of air temperature difference between the EGR and a bare roof with differences in relative humidity, net radiation, several measures of soil and surface temperature, and soil moisture as well as average solar radiation, air temperature and wind speed. The results implied that both the components of the EGR, such as green vegetation and the soil substrate layer, and the microclimate created by the EGR can feed back and contribute to the thermal performance of an EGR. Through this full-scale EGR research in a subtropical monsoon climate, we provide the scientific basis and actionable practices for green roof planning and design to alleviate the urban heat island effect towards designing climate-resilient cities.

Keywords: Extensive green roof; Experimental analysis; Outdoor cooling effect; Thermal performance; Subtropical monsoon climate 


\section{List of Abbreviations and Acronyms}

UHI Urban heat island

EGR Extensive green roof

BR Bare roof

CAM Crassulacean acid metabolism

LAI Leaf Area index

PCA Plant canopy analyzer

SVF Sky view factor

$\mathrm{T}_{\mathrm{a}} \quad$ Air temperature $\left({ }^{\circ} \mathrm{C}\right)$

RH Relative humidity (\%)

SR Solar radiation $\left(\mathrm{Wm}^{-2}\right)$

SR_up Incoming shortwave radiation $\left(\mathrm{Wm}^{-2}\right)$

SR_down Reflected shortwave radiation $\left(\mathrm{Wm}^{-2}\right)$

WS Wind speed $\left(\mathrm{m}^{-\mathrm{s}}\right)$

NR Net radiation $\left(\mathrm{Wm}^{-2}\right)$

$\mathrm{T}_{\mathrm{s} \_} \mathrm{TIR}$ Thermal infrared surface temperature $\left({ }^{\circ} \mathrm{C}\right)$

$\mathrm{T}_{\mathrm{s}_{-}} \mathrm{TC} \quad$ Thermocouple surface temperature $\left({ }^{\circ} \mathrm{C}\right)$

Soil_T Soil temperature $\left({ }^{\circ} \mathrm{C}\right)$

Soil_M Soil moisture $\left(\mathrm{m}^{3} / \mathrm{m}^{3}\right)$

Soil_HF Soil heat flux $\left(\mathrm{Wm}^{-2}\right)$
$\Delta \mathrm{T}_{\mathrm{a}}$

$\mathrm{T}_{\mathrm{a} \_ \text {daily }}$

Ta_daily_daytime

Ta_daily_nighttime

$\Delta \mathrm{T}_{\mathrm{a} \_ \text {daily }}$

$\Delta \mathrm{T}_{\mathrm{a} \_ \text {daily_daytime }}$

$\Delta \mathrm{T}_{\mathrm{a} \_ \text {daily_nighttime }}$

$\Delta \mathrm{T}_{\mathrm{a} \_}$hourly

SR_daytime

57
Air temperature above the EGR

$\left(T_{a \_} E G R\right)$ minus the BR $\left(T_{a \_} B R\right)$

$\left({ }^{\circ} \mathrm{C}\right)$

Average daily air temperature at corresponding height $\left({ }^{\circ} \mathrm{C}\right)$

Average daily air temperature during the day $\left({ }^{\circ} \mathrm{C}\right)$

Average daily air temperature during the night $\left({ }^{\circ} \mathrm{C}\right)$

Average daily air temperature difference between EGR and BR at corresponding height $\left({ }^{\circ} \mathrm{C}\right)$

Average daily air temperature difference during the day $\left({ }^{\circ} \mathrm{C}\right)$

Average daily air temperature difference during the night $\left({ }^{\circ} \mathrm{C}\right)$ Average hourly air temperature difference between EGR and BR at corresponding height $\left({ }^{\circ} \mathrm{C}\right)$ Day-time average solar radiation $\left(\mathrm{Wm}^{-2}\right)$ 


\section{Introduction}

Many cities around the world have been suffering from an increased urban heat island (UHI) effect due to urbanization and will likely experience more frequent, more intense, and longer lasting heat waves in the future (Perkins et al., 2012; Jim, 2015; Solcerova et al., 2017). Urban green spaces can mitigate UHI effects and provide important temperature regulating ecosystem services (Kong et al., 2016). However, available space for urban greening is limited in many cities due to dense urban forms and high economic land value (Santamouris, 2014; Xiao et al., 2014; Vijayaraghavan, 2016). Green (vegetated, eco or living) roofs have frequently been proposed as a way to increase the amount of green spaces in the urban area and, thereby, mitigate the UHI effect (Francis and Lorimer, 2011; Parizotto and Lamberts, 2011; Susca et al., 2011; Saadatian et al., 2013; Berardi et al., 2014; Santamouris, 2014; Solcerova et al., 2017; Calliari et al., 2019). Moreover, green roofs can also reduce building energy consumption (Theodosiou, 2003; Parizotto and Lamberts, 2011; Coma et al., 2016), decrease the quantity and increase the quality of rainwater runoff (Carpenter et al., 2016; Sims et al., 2016), extend roof life (Teemusk and Mander, 2009), improve urban air quality (Yang et al., 2008; Rowe, 2011), and provide aesthetic appeal and amenity spaces (Kohler et al., 2002; Kosareo and Ries, 2007). Green roofs are an innovative way to increase the health and sustainability of buildings and cities (Bevilacqua et al., 2016).

Green roofs consist of several components, including vegetation, substrate, filter fabric, drainage material, root barrier, and thermal insulation (Saadatian et al., 2013; Berardi, 2016; Vijayaraghavan, 2016). Depending on the vegetation type, substrate depth, construction material, maintenance level, and allocated usage, green roofs are generally classified as extensive and intensive (Saadatian et al., 2013; Berardi et al., 2014; Li and Yeung, 2014; El Bachawati et al., 2016; Bevilacqua et al., 2016; Vijayaraghavan, 2016). Intensive green roofs usually have a deep and heavy substrate (substrate depth of more than $15-20 \mathrm{~cm}$ and typically more than $290 \mathrm{~kg} / \mathrm{m}^{2}$ ) and feature a variety of plants ranging from grasses and forbs to small trees, which require intensive maintenance and involve high costs. Intensive green roofs are usually designed for complete accessibility of new buildings, 
considering the extra weight of the green roof during the design of the building's structural components (Williams et al., 2010; Jim et al., 2011; Bevilacqua et al., 2016; Vijayaraghavan, 2016). In contrast, extensive green roofs (EGRs) are characterized by a thin substrate layer (typically less than $10-15 \mathrm{~cm}$ ); low weight (typically $70-170 \mathrm{~kg} / \mathrm{m}^{2}$ ); a limited variety of vegetation types including moss, grasses and succulents; minimal maintenance; low capital cost; and are less likely to be designed for frequent human access. EGRs are suited for installation on existing buildings without enhancement of structural building support (Bevilacqua et al., 2016; Vijayaraghavan, 2016) and are, therefore, frequently recommended in urban areas (MacIvor et al., 2016).

Green roof substrates can insulate the inside of the building from outdoor heat, while vegetation cools the local environment through shading, reflection of solar radiation, and evapotranspiration (Takakura et al., 2000; Niachou et al., 2001; Solcerova et al., 2017). There have been many recent evaluations of the thermal performance of EGRs (Parizotto and Lamberts, 2011; Berardi, 2014; Vijayaraghavan, 2016; Solcerova et al., 2017), and particularly their cooling benefits during warm seasons (MacIvor et al., 2016).

Most previous studies used field observations (Niachou et al., 2001; Parizotto and Lamberts, 2011; Olivieri et al., 2013; Bevilacqua et al., 2016; MacIvor et al., 2016; Solcerova et al., 2017) or complex mathematical models (Niachou et al., 2001; Ouldboukhitine et al., 2011; Ascione et al., 2013; Olivieri et al., 2013) to quantify the cooling benefit performance of EGRs by comparing the air or surface temperature of vegetated roofs with that of bare roofs. Numerical models are generally employed to simulate the cooling potential of an EGR by comparing different scenarios, especially with or without EGR, however, they are often not appropriately applied to study the underlying mechanisms governing the thermal performance of an EGR (Ascione et al., 2013; Kong et al., 2016). Improving the accuracy of numerical models is still a challenge due to the complexity of the heat and mass transfer in green roofs and complex structure of the green roof systems (Bevilacqua et al., 2016). Therefore, experimental setups with direct measurements remain the commonly used method to investigate the cooling effects of EGRs (Parizotto and Lamberts, 2011; Bevilacqua et al., 2016). 

temperature or indoor air temperature (Berardi et al., 2014; Bevilacqua et al. 2016; Vijayaraghavan, 2016). For instance, in an experimental analysis of an EGR installed on a university building in Cosenza, Italy under typical Mediterranean climate conditions, Bevilacqua et al. (2016) found that an EGR reduced surface temperatures by $12^{\circ} \mathrm{C}$ (indoor air temperatures by $2.3^{\circ} \mathrm{C}$ ) in the summer.

117 Experimental studies have shown that air temperature above green roofs is generally lower than above traditional non-green roofs, but the vertical cooling extent has been found to be limited to a couple of meters above roof surface (Peng and Jim, 2015; Solcerova et al., 2017). However, the vertical extent of this temperature reduction remains uncertain and is site-specific (Solcerova et al., 2017). Through air temperature comparisons, some studies have also found that at daytime during the summer, EGRs may exhibit warming effects above the near-ground layer (Wong et al., 2007; Solcerova et al., 2017; Peng et al., 2019). In an observational study of sedum-covered EGRs in Utrecht (NL), Solcerova et al. (2017) showed that air temperature above such a roof surface was colder at night and slightly warmer during the day compared to a white gravel roof during a $24 \mathrm{~h}$ period. The vertical thermal performance characteristics and the reason for such warming effects during the daytime, as well as whether this phenomenon is common or not, both require further study, especially with regard to optimizing the cooling effect and temperature regulating ecosystem services of EGRs.

Previous studies based on observational data were often conducted during short measurement periods at one height with small plots or modular test beds, which makes it difficult to extrapolate to other contexts and climate conditions. In particular, to our knowledge, few experimental studies have been developed with a full-scale EGR at different heights in China (Xiao et al., 2014; Yang et al., 2015; Peng et al., 2019). Furthermore, one of the driving forces behind the upsurge in EGR research is the need to provide solid scientific knowledge to optimize EGR function and delivery of ecosystem services to guide sustainable urban design and management. Consequently, city-specific research is 
building characteristics and climatic conditions.

To date, the vertical thermal gradient of EGRs has not been thoroughly studied and understood. In this paper, we compare microclimate observations over a full-scale, sedum-covered EGR and a bare roof (BR) in Nanjing, China in order to 1) characterize the thermal performance of an EGR at three vertical heights $(30,60$ and $120 \mathrm{~cm})$ under different weather conditions (sunny, cloudy, and rainy) for a full summer in a subtropical monsoon climate; and 2) evaluate the impacts of microclimate parameters as well as plant characteristics on thermal performance of the EGR. The results of this study will provide additional insight into the summertime thermal performance of EGRs to guide their design to cool the outdoor thermal environment more effectively in a subtropical monsoon climate.

\section{Experiment and Methods}

\subsection{Study site and roof systems}

We conducted microclimate observations on the full-scale EGR of the Executive Office Building at Nanjing Jinling Elementary School (JLES) on Xianlin Campus (latitude $32.109^{\circ} \mathrm{N}$, longitude $\left.118.967^{\circ} \mathrm{E}\right)$, located in Nanjing, the capital of Jiangsu Province, China (Fig.1 a-c). Nanjing has a subtropical monsoon climate with four seasons including a hot, wet summer. According to Nanjing meteorological data for 1951-2010, the summer (daily mean air temperature $\geq 22^{\circ} \mathrm{C}$ in five consecutive days) lasts, on average, for 119 days (Pan, 2011). The mean annual temperature is $15.4{ }^{\circ} \mathrm{C}$, with mean monthly temperature ranging between $24.4^{\circ} \mathrm{C}$ and $27.8{ }^{\circ} \mathrm{C}$ for June to August.

The mean daily maximum temperature is $31.9{ }^{\circ} \mathrm{C}$, and the daily peak is $39.7^{\circ} \mathrm{C}$ in July. The mean annual precipitation is about $1100 \mathrm{~mm}$, with approximately $80 \%$ of the rainfall during the wet season (April to September).

The Executive Office Building at JLES was built in 2011. The building is a five-story brickconcrete composite structure, about $16.5 \mathrm{~m}$ high, with a plane roof (slope around 2\%) (Figs. $1 \mathrm{c}, \mathrm{d}$ ). The office layout on the fifth floor is basically symmetrical (Fig.1 e). The total roof area is 1016.3 $\mathrm{m}^{2}$. The roof was divided into two approximately equal plots for comparison: an EGR plot (509.0 

2016 (Fig.1 f, g). The drainage system and the maintenance passageway (total $64.6 \mathrm{~m}^{2}$ ) on the roof were not covered by the EGR (Fig.1 g). The growing media and plants (Sedum lineare) for the EGR were installed using pre-grown vegetated modules (length $0.50 \mathrm{~m}$, width $0.33 \mathrm{~m}$, height $0.11 \mathrm{~m}$, not including the canopy) featuring a carrier with a $7.0 \mathrm{~cm}$ thick soil substrate layer.
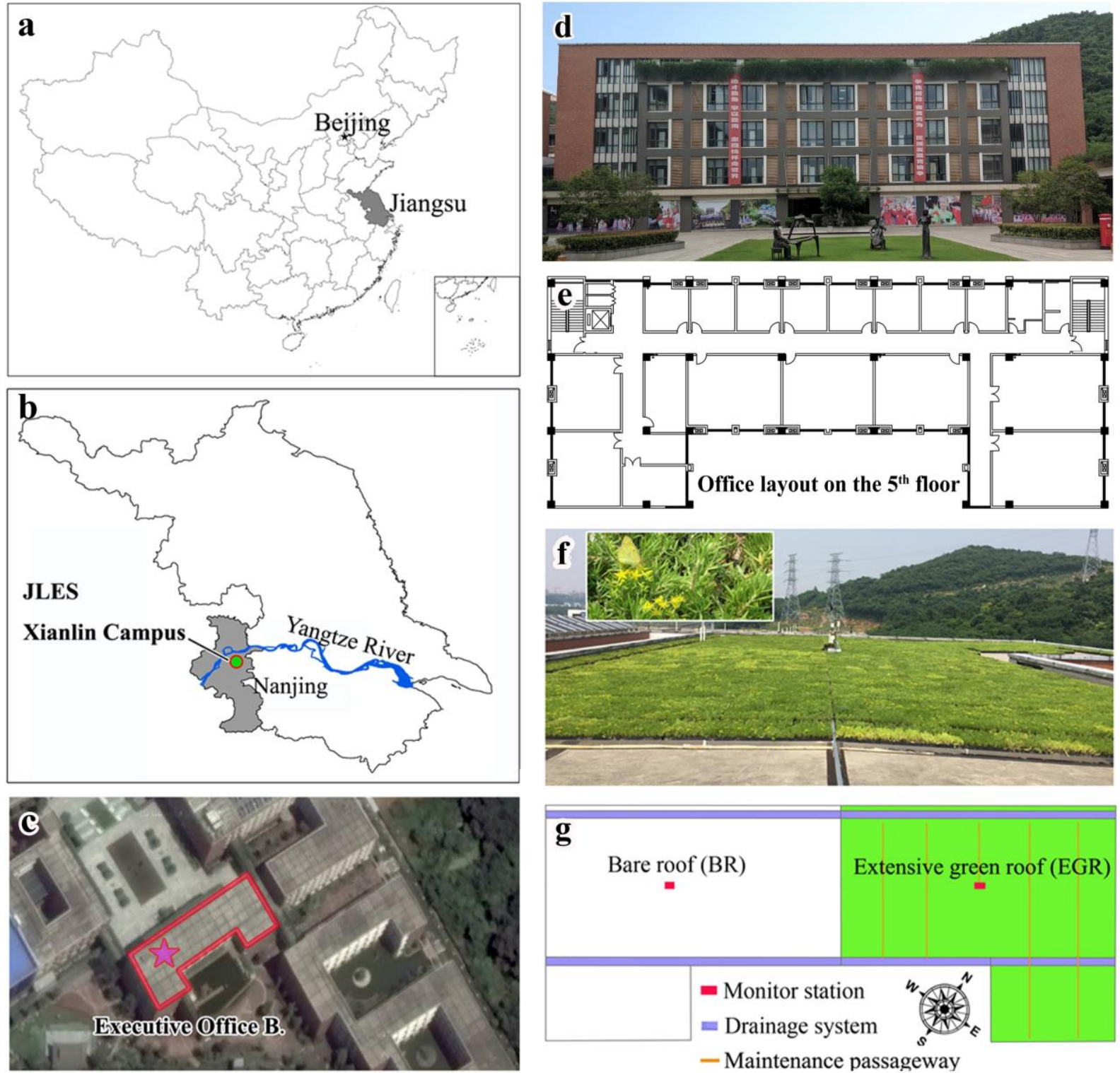

Fig. 1. Study area and observation sites.

Sedum species are often regarded as an ideal and reliable choice for planting on EGRs around the world due to their unique characteristics: they grow with relatively shallow roots, are able to store 
excess water in leaves or stems, and have crassulacean acid metabolism (CAM) to limit transpiration and reduce water loss (Van Woert et al., 2005; MacIvor and Lundholm, 2011). CAM plants can increase their water use efficiency by allowing stomatal opening and $\mathrm{CO}_{2}$ storage during nighttime, which lowers daytime evaporation rates. Sedum species are also able to close their stomata during the daytime to avoid water loss from transpiration (Ting, 1985).

The soil substrate layer consists of a combination of powdered vermiculite aggregate (30\%), peat moss soil $(30 \%)$, ceramsite $(30 \%)$, organic matter $(10 \%)$, a $0.1 \mathrm{~cm}$ geotextile filter layer, and a 3.9 cm multi-functional water storage and drainage layer (Fig. 2). The leaf area index (LAI) of the EGR measured with the Li-Cor LAI-2200C Plant Canopy Analyzer (PCA) was 2.6, the plant coverage was $90 \%$, and the mean height was $8 \mathrm{~cm}$ at the time of installation. The BR control plot mainly consists of three layers: concrete mortar, extruded polystyrene thermal insulation, and reinforced concrete roof slab (Fig. 2). Although low hills to the south-east of the building block the sun in the early morning (Fig.1 c, f), the site is well exposed with a sky view factor (SVF) close to 1, allowing almost unobstructed solar access and energy dissipation by outgoing terrestrial radiation.

\subsection{Monitoring systems and measurement period}

We set up two monitoring stations on a pole anchored by concrete ballast in the center of the BR and EGR, respectively (Figs. 1g, 2). Each station was equipped with one HOBO U30 (Onset Computers, Bourne, MA, USA) and one CR1000 (Campbell Scientific, Logan, UT, USA) data logger to record air temperature $\left(\mathrm{T}_{\mathrm{a}}\right)$, relative humidity $(\mathrm{RH})$, solar radiation $(\mathrm{SR})$, wind speed $(\mathrm{WS})$, rainfall, net radiation defined as the total incoming radiation of all wavelengths minus the reflected and emitted radiation $(\mathrm{NR})$, thermal infrared surface temperature $\left(\mathrm{T}_{\mathrm{s}_{-}} \mathrm{TIR}\right)$, thermocouple surface temperature $\left(\mathrm{T}_{\mathrm{S} \_} \mathrm{TC}\right)$, soil temperature $($ Soil_T), soil moisture (Soil_M), and soil heat flux (Soil_HF, the downward energy flux is positive, the upwards flux negative) (Table 1, Fig. 2). All sensors were scanned every minute, and averaged data recorded at 5-minute intervals.

Sensors at each monitoring station included: 1) three air temperature and relative humidity sensors at 30,60, and $120 \mathrm{~cm}$ height above the BR and vegetated layer of the EGR; 2) a weatherproof 
199 infrared radiometer; 3) thermocouple surface temperature sensor with an outer insulating material 200 (one on the BR, two on the EGR, Fig. 2); 4) a net radiometer and two solar radiation sensors. Note 201 that the upward and downward shortwave radiation of the BR and EGR were measured using a pair 202 of solar radiation sensors (Fig. 2). The monitoring station on the EGR also contained four soil 203 temperature and moisture sensors and two soil heat flux meters, buried $4.5 \mathrm{~cm}$ in the substrate layer 204 (Fig. 2). In addition, a rain gauge and a wind speed sensor were installed at the monitoring station 205 on the BR.

206 The measuring period was a typical hot and humid summer, June 6 - September 30, 2016, 207 included 39 rainy days (total precipitation of $827 \mathrm{~mm}$ ) and two heat wave events (defined as three 208 consecutive days with daily maximum temperature $\geq 35^{\circ} \mathrm{C}$ ) (July 20 - August 2 , August 11-August 209 20, see grayed regions in Fig. A2). Irrigation is essential during heat wave events, and the EGR was 210 watered by hand at night on July 26 and July 29.

211

212 Table 1 Equipment specifications and main sensor parameters

\begin{tabular}{|c|c|c|c|c|c|c|}
\hline Equipment & Smart sensors & Product model & Parameter & Accuracy & Resolution & Installation height \\
\hline \multirow[t]{3}{*}{ HOBO U30 } & Temperature/RH & S-THB-M002 & Temperature & $\pm 0.2^{\circ} \mathrm{C}\left(0 \sim 50^{\circ} \mathrm{C}\right)$ & $0.02^{\circ} \mathrm{C}$ & $\mathrm{T}_{\mathrm{a}}, \mathrm{RH}: 0.3 \mathrm{~m}, 0.6 \mathrm{~m}$ \\
\hline & sensor & & Relative humidity & $\pm 2.5 \%(10 \sim 90 \%)$ & $0.1 \%$ & \\
\hline & Solar radiation sensor & S-LIB-M003 & Light intensity & $\pm 10 \mathrm{~W} / \mathrm{m}^{2}$ & $1.25 \mathrm{~W} / \mathrm{m}^{2}$ & $0.3 \mathrm{~m}$ \\
\hline \multirow[t]{12}{*}{ CR1000 } & Temperature/RH & HMP155A & Temperature & $\pm 0.1^{\circ} \mathrm{C}$ & $0.02^{\circ} \mathrm{C}$ & $\mathrm{T}_{\mathrm{a}}, \mathrm{RH}: 1.2 \mathrm{~m}$ \\
\hline & sensor & & Relative humidity & $\pm 1 \%$ & $0.1 \%$ & \\
\hline & Infrared radiometer & SI-111 & Surface temperature & $\pm 0.2^{\circ} \mathrm{C}\left(-10^{\circ} \mathrm{C} \sim 65^{\circ} \mathrm{C}\right)$ & $0.05^{\circ} \mathrm{C}$ & $0.8 \mathrm{~m}$ \\
\hline & Thermocouple surface & AV-10LT & Surface temperature & $\pm 0.2^{\circ} \mathrm{C} \quad\left(-40^{\circ} \mathrm{C} \sim 70^{\circ} \mathrm{C}\right)$ & $0.01^{\circ} \mathrm{C}$ & Surface of BR and EGR; \\
\hline & Temperature sensor & & & & & Substrate layer surface of EGR \\
\hline & Net radiometer & NR Lite2 & Solar net radiation & $<1.0 \%$ & $0.01 \mathrm{~V} / \mathrm{W} \cdot \mathrm{m}^{-2}$ & $0.8 \mathrm{~m}$ \\
\hline & Soil temperature & $\mathrm{AV}-10 \mathrm{~T}$ & Soil temperature & $\pm 0.2^{\circ} \mathrm{C}\left(0 \sim 70^{\circ} \mathrm{C}\right)$ & $0.01^{\circ} \mathrm{C}$ & $4.5 \mathrm{~cm}$ under the soil surface \\
\hline & sensor & & & & & $4.5 \mathrm{~cm}$ under the soil surface \\
\hline & Soil moisture sensor & CS616 & Soil moisture & $\pm 2.5 \%$ & $0.1 \%$ & $4.5 \mathrm{~cm}$ under the soil surface \\
\hline & Soil heat flux meter & HFP01 & Soil heat flux & $\pm 5 \%$ & $0.05 \mathrm{~V} / \mathrm{W} \cdot \mathrm{m}^{-2}$ & \\
\hline & Wind speed sensor & RM Young03001 & Wind speed & $\pm 0.5 \mathrm{~m} / \mathrm{s}$ & $0.5 \mathrm{~m} / \mathrm{s}$ & $1.5 \mathrm{~m}$ \\
\hline & Rainfall sensor & TE525MM & Rainfall & $\pm 1 \%(\leqq 10 \mathrm{~mm} / \mathrm{hr})$ & $0.1 \mathrm{~mm}$ & $1.2 \mathrm{~m}$ \\
\hline
\end{tabular}




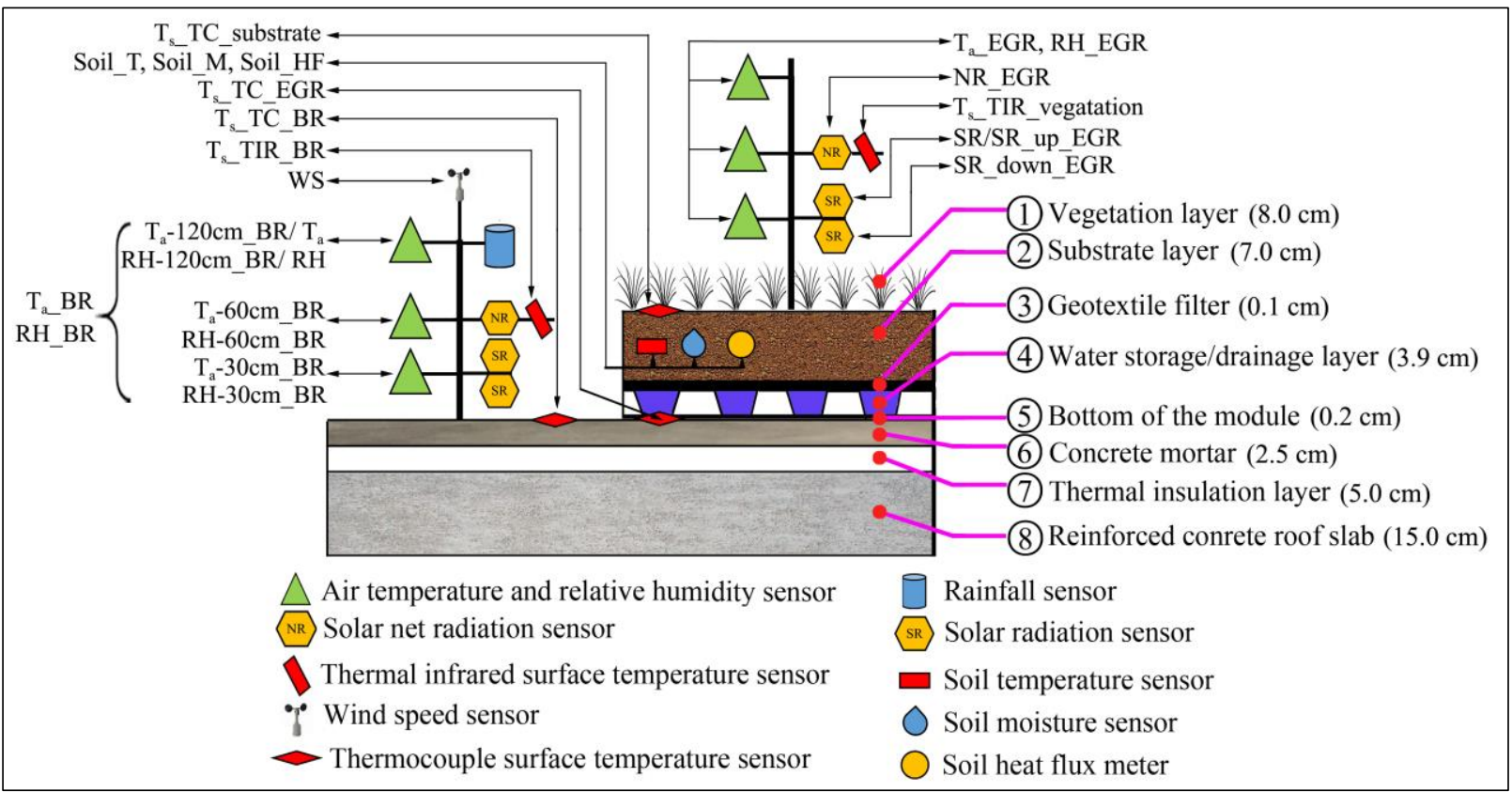

Fig. 2. Plot illustrating the position of the installed sensors and nomenclature of observed variables.

\subsection{Statistical analysis}

In the following sections, the outdoor air temperature difference $\left(\Delta T_{a}\right)$ is defined as the air temperature above the EGR $\left(T_{a \_} E G R\right)$ minus the BR $\left(T_{a \_} B R\right)$ at any given time and height $(30 \mathrm{~cm}$, $60 \mathrm{~cm}$, and $120 \mathrm{~cm}$ ). If $\Delta T_{a}<0^{\circ} \mathrm{C}$, it shows that the EGR has a cooling effect, and vise-visa, when $\Delta T_{a} \geq 0{ }^{\circ} \mathrm{C}$, it indicates that the EGR has a warming effect.

\subsubsection{The overall daily thermal performance of the EGR}

Firstly, we performed a statistical analysis of the average daily air temperature $\left(T_{a-}\right.$ daily) and the daily air temperature difference ( $\Delta T_{a_{-}}$daily) at 30,60 and $120 \mathrm{~cm}$ between EGR and BR, respectively. Then, the average, minimum, maximum, range, and standard deviation of daily air temperature during the day-time and night-time ( $T_{a-}$ daily_daytime, $T_{a-}$ daily_nighttime $)$ and the daily air

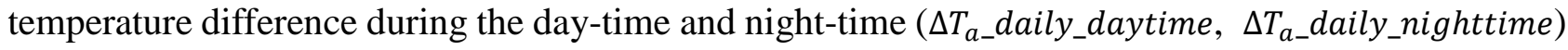
at the three heights were calculated based on the daily sunrise and sunset time (Appendix, Table A1, Fig. A1). Finally, based on previous literature (Standardization Administration of China, 2008; Jim, 2015; Solcerova et al., 2017), we used two indices, the total daily precipitation (mm) and day-time average solar radiation (SR_daytime, $\mathrm{W} / \mathrm{m}^{2}$ ) at the site to define three weather scenarios (sunny, 
cloudy, and rainy). Days with no precipitation and SR_daytime $\geq 350 \mathrm{~W} / \mathrm{m}^{2}$ were considered sunny (clear sky); days with no precipitation and SR_daytime $<350 \mathrm{~W} / \mathrm{m}^{2}$ were considered cloudy; and days with precipitation $>0.1 \mathrm{~mm}$ were considered rainy. Then, $\Delta T_{a_{-}}$daily under these three weather scenarios were calculated and summarized (Appendix, Tables A2, A3).

\subsubsection{EGR daily thermal performance extremes}

To further understand the thermal performance of the EGR, we summarized the days with extreme values (highest or lowest daily thermal performance) during the study period at the three height levels (Tables 2, 3). As all the days with extreme values were either sunny or rainy days, we selected days with extreme values from cloudy days only based on the same approach (Tables 4,5$)$.

\subsubsection{EGR hourly thermal performance on selected days}

Based on the high frequency of extreme values, we selected four days as time snapshots from each of the sunny, rainy and cloudy weather scenarios (Tables 3, 5). Then, we quantified the hourly thermal performance ( $\Delta T_{a_{-}}$hourly) of the EGR (either cooling or warming effect) at three heights for the selected twelve days (Figs. 3, 4).

\subsubsection{Regression analysis to assess the summer thermal performance of the EGR}

We selected 14 environmental factors that may affect the $\Delta T_{a}$, including the difference of microclimate conditions between the two roof types and the properties of soil layer and vegetation mass (Table A4). Then, we conducted a multiple linear regression analysis to assess which variables were most strongly associated with $\Delta T_{a}$ at 30,60 , and $120 \mathrm{~cm}$ height using daily and hourly interval data, respectively (Table 6). This analysis was performed using a stepwise selection method (inclusion with a 0.05 or lower probability of the F-statistic, and removal with a 0.1 or larger probability of F). Standardized model coefficients, the coefficient of determination $\left(\mathrm{R}^{2}\right)$, and model p-value were used as criteria to identify the strongest predictors (Table 6).

\section{Results}

\subsection{EGR daily thermal performance}

Observations show that the EGR exhibited a weak, daily outdoor air temperature cooling effect 
at all three observation heights. The average daily air temperature differences $\left(\Delta T_{a_{-}}\right.$daily) at 30,60 and $120 \mathrm{~cm}$ were $-0.09,-0.23$ and $-0.09{ }^{\circ} \mathrm{C}$, respectively (Table A1), with a greater cooling effect at $60 \mathrm{~cm}$ height than at 30 and $120 \mathrm{~cm}$. These data indicate that the cooling effect first increases and then decrease as height increases, though it is recognized that these data do not indicate if these are continuous or step wise changes (Table A1, Fig. A1).

Further analysis shows that nighttime daily average air temperature differences $\left(\Delta T_{a-}\right.$ daily_nighttime) at 30,60 and $120 \mathrm{~cm}$ heights were $-0.63,-0.40$, and $-0.15{ }^{\circ} \mathrm{C}$, respectively, which was markedly lower than the daytime average daily air temperature differences $\left(\Delta T_{a-}\right.$ daily_daytime $)$ at each corresponding height $\left(0.32,-0.11,-0.04{ }^{\circ} \mathrm{C}\right.$, respectively) (Table A1). These data show that the EGR had a very obvious cooling effect at nighttime, but during the day, it exhibited a warming effect at 30cm height and a slight cooling effect at 60 and $120 \mathrm{~cm}$ heights.

During the whole study period, there was only one night in which the EGR produced a slight warming effect $\left(\Delta T_{a_{-}}\right.$daily_nighttime $\left.\geq 0^{\circ} \mathrm{C}, 0.01^{\circ} \mathrm{C}\right)$ at height $120 \mathrm{~cm}$. However, on 89,27 and 31 days the EGR produced a warming effect at 30, 60 and $120 \mathrm{~cm}$ heights, respectively, during the daytime $\left(\Delta T_{a-}\right.$ daily_daytime $\left.\geq 0^{\circ} \mathrm{C}\right)$. The duration, mean and maximum values of the daily day-time warming effect at $30 \mathrm{~cm}$ height $\left(\Delta T_{a_{-}}\right.$daily_daytime $)$were longer and higher (89 days, 0.47 and $\left.1.59{ }^{\circ} \mathrm{C}\right)$ than those at $60\left(27\right.$ days, 0.17 and $\left.0.59{ }^{\circ} \mathrm{C}\right)$ and $120 \mathrm{~cm}\left(31\right.$ days, 0.11 and $\left.0.38{ }^{\circ} \mathrm{C}\right)($ Table A1). All of these data indicated that the cooling effect at night was very pronounced and consistent, but the daytime cooling effect was quite inconsistent, and that the daytime warming effect at $30 \mathrm{~cm}$ height causes a weaker daily cooling effect at $30 \mathrm{~cm}$ compared with 60 and $120 \mathrm{~cm}$.

With the increase of observation height (from 30 to $60 \mathrm{~cm}$, and then $120 \mathrm{~cm}$ ), the amplitudes of the $\Delta T_{a_{-}}$daily, $\Delta T_{a_{-}}$daily_daytime and $\Delta T_{a_{-}}$daily_nighttime significantly decreased (Appendix, Fig. A1). Their ranges were $0.93,2.02,1.83{ }^{\circ} \mathrm{C}$ at $30 \mathrm{~cm}$ height, $0.58,1.12,1.26^{\circ} \mathrm{C}$ at $60 \mathrm{~cm}$ height, and $0.37,0.64,0.65^{\circ} \mathrm{C}$ at $120 \mathrm{~cm}$ height, respectively, and the standard deviations of $\Delta T_{a_{-}}$daily were also reduced from $0.19,0.41,0.32$ at $30 \mathrm{~cm}$ height, to $0.12,0.20,0.21$ at $60 \mathrm{~cm}$ height, and to 0.06 , $0.12,0.11$ at $120 \mathrm{~cm}$ height, respectively (Table A1). These data suggest that the impact of the EGR 
on outdoor daily air temperature differences (either cooling or warming effect) decreased with the increase of observation height. The results imply that the heating or cooling transfer from the BR or EGR surface to air at daytime or nighttime is noticeably confined to the near-ground air layer, and the impact decays rapidly with increasing height.

The strongest cooling and warming effects happened during sunny days, followed by cloudy and rainy days at each given observation height (Tables A2, A3). For example, at $30 \mathrm{~cm}$ height and cloudfree conditions, when $\Delta T_{a_{-}}$daily $<0^{\circ} \mathrm{C}$, the average $\Delta T_{a_{-}}$daily was $-0.22{ }^{\circ} \mathrm{C}$, while it was $-0.16{ }^{\circ} \mathrm{C}$ during cloudy and rainy days (Table A2). For $\Delta T_{a_{-}}$daily $\geq 0{ }^{\circ} \mathrm{C}$, the maximum and average values of $\Delta T_{a_{-}}$daily at $30 \mathrm{~cm}$ height on sunny days were 0.37 and $0.15^{\circ} \mathrm{C}$, respectively, but they were 0.18 and $0.09^{\circ} \mathrm{C}$ on cloudy days, and 0.23 and $0.09^{\circ} \mathrm{C}$ on rainy days (Table A3). These results show that the magnitude of $\Delta T_{a_{-}}$daily varied almost consistently in the order sunny day> cloudy day> rainy day.

\subsection{EGR daily thermal performance extremes}

The analysis of extreme values of $\Delta T_{a_{-}}$daily, $\Delta T_{a_{-}}$daily_daytime, and $\Delta T_{a_{-}}$daily_nighttime at the three heights shows that the EGR's performance was most extreme on both sunny and rainy days. Thirteen extreme events occurred on 6 sunny days, and five events occurred on 4 rainy days (Tables $2,3)$.

The minimum values of $\Delta T_{a_{-}}$daily and $\Delta T_{a_{-}}$daily_daytime (i.e. the strongest cooling effect) at three heights occurred on June 13 , a sunny day with relatively high soil moisture $\left(0.260 \mathrm{~m}^{3} / \mathrm{m}^{3}\right)$, low air temperature $\left(25.78^{\circ} \mathrm{C}\right)$, and low wind speed $(0.6 \mathrm{~m} / \mathrm{s})$, and June 15 , a rainy day with little rainfall $(0.2 \mathrm{~mm})$, relatively high soil moisture $\left(0.137 \mathrm{~m}^{3} / \mathrm{m}^{3}\right)$, and low air temperature $\left(26.79{ }^{\circ} \mathrm{C}\right)$ (Tables 2 , 3). Meanwhile, the maximum values of $\Delta T_{a-}$ daily (i.e. the strongest daily warming effect at $30 \mathrm{~cm}$ height) and $\Delta T_{a-}$ daily_daytime (the strongest day-time warming effect at the three heights) all occurred on sunny days (July 23, 26-28) with relatively low soil moisture $\left(<0.07 \mathrm{~m}^{3} / \mathrm{m}^{3}\right)$ and high air temperature $\left(>33^{\circ} \mathrm{C}\right)$ (Tables 2,3$)$.

In addition, the minimum values of $\Delta T_{a_{-}}$daily_nighttime at the three heights (i.e. the strongest cooling effect) occurred on a sunny day, August 30, with very low soil moisture $\left(0.0278 \mathrm{~m}^{3} / \mathrm{m}^{3}\right)$, 
relatively low air temperature $\left(25.32{ }^{\circ} \mathrm{C}\right)$ and low relative humidity $(52.0 \%)$. The maximum values

310 for $\Delta T_{a_{-}}$daily_nighttime all occurred on rainy days with heavy rainfall $(>28 \mathrm{~mm})$, high soil moisture

$311\left(>0.16 \mathrm{~m}^{3} / \mathrm{m}^{3}\right)$, high relative humidity $(>91 \%)$ and low air temperature $\left(<24{ }^{\circ} \mathrm{C}\right)($ Tables 2,3$)$.

312

313 Table 2 Summary of extreme thermal values and days at three observation heights $(30,60$ and $120 \mathrm{~cm})$.

\begin{tabular}{lccccccc}
\hline $\begin{array}{l}\text { Minimum/ Height } \\
\text { maximum }\end{array}$ & $\begin{array}{c}\Delta T_{a_{-} \text {daily }} \\
\left({ }^{\circ} \mathrm{C}\right)\end{array}$ & $\begin{array}{c}\text { Time } \\
(\mathrm{MM} / \mathrm{DD})\end{array}$ & $\begin{array}{c}\Delta T_{a_{-} \text {daily_daytime }} \\
\left({ }^{\circ} \mathrm{C}\right)\end{array}$ & $\begin{array}{c}\text { Time } \\
(\mathrm{MM} / \mathrm{DD})\end{array}$ & $\begin{array}{c}\Delta T_{a_{-} \text {daily_nighttime }} \\
\left({ }^{\circ} \mathrm{C}\right)\end{array}$ & $\begin{array}{c}\text { Time } \\
(\mathrm{MM} / \mathrm{DD})\end{array}$ \\
\hline Minimum & $30 \mathrm{~cm}$ & -0.56 & $6 / 15$ & -0.43 & $6 / 15$ & -1.85 & $8 / 30$ \\
& $60 \mathrm{~cm}$ & -0.59 & $6 / 13$ & -0.53 & $6 / 13$ & -1.27 & $8 / 30$ \\
& $120 \mathrm{~cm}$ & -0.29 & $6 / 13$ & -0.26 & $6 / 13$ & -0.64 & $7 / 26$ \\
Maximum & $30 \mathrm{~cm}$ & 0.37 & $7 / 28$ & 1.59 & $7 / 26$ & -0.09 & $7 / 4$ \\
& $60 \mathrm{~cm}$ & -0.01 & $7 / 23$ & 0.59 & $7 / 26$ & -0.06 & $9 / 30$ \\
& $120 \mathrm{~cm}$ & 0.08 & $7 / 27$ & 0.38 & $7 / 27$ & 0.01 & $9 / 29$ \\
\hline
\end{tabular}

314

315 Table 3 Summary of environmental characteristics on the days with extreme thermal values at three observation

316 heights.

\begin{tabular}{|c|c|c|c|c|c|c|c|}
\hline $\begin{array}{l}\text { Date } \\
(\mathrm{MM} / \mathrm{DD})\end{array}$ & $\begin{array}{l}\text { Weather } \\
\text { scenarios }\end{array}$ & Frequency & $\begin{array}{l}\text { SR_daytime } \\
\left(\mathrm{W} / \mathrm{m}^{2}\right)\end{array}$ & $\begin{array}{l}\text { Soil_M } \\
\left(\mathrm{m}^{3} / \mathrm{m}^{3}\right)\end{array}$ & $\begin{array}{l}\text { WS } \\
(\mathrm{m} / \mathrm{s})\end{array}$ & $\begin{array}{l}\mathrm{T}_{\mathrm{a}}-120 \mathrm{~cm} \_\mathrm{BR} \\
\left({ }^{\circ} \mathrm{C}\right)\end{array}$ & $\begin{array}{l}\text { RH-120cm_BR } \\
(\%)\end{array}$ \\
\hline $6 / 13 *$ & Sunny & 4 & 430 & 0.260 & 0.6 & 25.78 & 73.5 \\
\hline $6 / 15^{*}$ & Rainy $(0.2 \mathrm{~mm})$ & 2 & 163 & 0.137 & 1.1 & 26.79 & 68.7 \\
\hline $7 / 4 *$ & Rainy (77mm) & 1 & 107 & 0.350 & 1.1 & 23.37 & 96.4 \\
\hline $7 / 23$ & Sunny & 1 & 496 & 0.068 & 1.5 & 33.40 & 61.4 \\
\hline $7 / 26^{*}$ & Sunny & 3 & 462 & 0.036 & 1.1 & 34.45 & 59.6 \\
\hline $7 / 27 *$ & Sunny & 2 & 426 & 0.036 & 1.3 & 33.81 & 61.6 \\
\hline $7 / 28$ & Sunny & 1 & 448 & 0.037 & 1.1 & 34.22 & 62.0 \\
\hline $8 / 30 *$ & Sunny & 2 & 478 & 0.028 & 0.6 & 25.32 & 52.0 \\
\hline $9 / 29 *$ & Rainy (38.8mm) & 1 & 50 & 0.164 & 2.1 & 17.87 & 91.7 \\
\hline $9 / 30 *$ & Rainy $(28.9 \mathrm{~mm})$ & 1 & 61 & 0.208 & 1.1 & 18.83 & 95.8 \\
\hline $6 / 6-9 / 30$ & -- & -- & 319 & 0.129 & 1.1 & 27.15 & 74.8 \\
\hline
\end{tabular}

317

$\left(^{*}\right)$ - day selected for further hourly analysis due to its higher frequency of extreme value.

318 Note: for the nomenclature of variables please see Fig. 2 and the list of abbreviations and acronyms. 
321 Table 4 Summary of extreme values on cloudy days at three observation heights.

\begin{tabular}{|c|c|c|c|c|c|c|c|}
\hline $\begin{array}{l}\text { Minimum/ } \\
\text { maximum }\end{array}$ & Height & $\begin{array}{c}\Delta T_{a-} \text { daily } \\
\left({ }^{\circ} \mathrm{C}\right)\end{array}$ & $\begin{array}{c}\text { Time } \\
(\mathrm{MM} / \mathrm{DD})\end{array}$ & $\begin{array}{c}\Delta T_{a-} \text { daily_daytime } \\
\left({ }^{\circ} \mathrm{C}\right)\end{array}$ & $\begin{array}{c}\text { Time } \\
(\mathrm{MM} / \mathrm{DD})\end{array}$ & $\begin{array}{c}\Delta T_{a_{-}} \text {daily_nighttime } \\
\left({ }^{\circ} \mathrm{C}\right)\end{array}$ & $\begin{array}{c}\text { Time } \\
(\mathrm{MM} / \mathrm{DD})\end{array}$ \\
\hline \multirow[t]{3}{*}{ Minimum } & $30 \mathrm{~cm}$ & -0.38 & $6 / 6$ & -0.16 & $6 / 6$ & -0.95 & $9 / 8$ \\
\hline & $60 \mathrm{~cm}$ & -0.42 & $6 / 6$ & -0.53 & $6 / 6$ & -0.60 & $7 / 16$ \\
\hline & $120 \mathrm{~cm}$ & -0.21 & $6 / 6$ & -0.19 & $6 / 6$ & -0.39 & $7 / 16$ \\
\hline \multirow[t]{3}{*}{ Maximum } & $30 \mathrm{~cm}$ & 0.18 & $8 / 19$ & 0.86 & $8 / 19$ & -0.30 & $7 / 10$ \\
\hline & $60 \mathrm{~cm}$ & -0.12 & $8 / 19$ & 0.13 & $8 / 19$ & -0.18 & $6 / 9$ \\
\hline & $120 \mathrm{~cm}$ & 0.03 & $8 / 19$ & 0.09 & $7 / 16$ & -0.03 & $9 / 14$ \\
\hline
\end{tabular}

323 Table 5 Summary of environmental characteristics on cloudy days with extreme values at three observation heights.

\begin{tabular}{lllllll}
\hline $\begin{array}{l}\text { Date } \\
(\mathrm{MM} / \mathrm{DD})\end{array}$ & Frequency & $\begin{array}{l}\text { SR_daytime } \\
\left(\mathrm{W} / \mathrm{m}^{2}\right)\end{array}$ & $\begin{array}{c}\text { Soil_M } \\
\left(\mathrm{m}^{3} / \mathrm{m}^{3}\right)\end{array}$ & $\begin{array}{l}\text { WS } \\
(\mathrm{m} / \mathrm{s})\end{array}$ & $\begin{array}{c}\mathrm{T}_{\mathrm{a}}-120 \mathrm{~cm} \_\mathrm{BR} \\
\left({ }^{\circ} \mathrm{C}\right)\end{array}$ & $\begin{array}{l}\text { RH-120cm_BR } \\
(\%)\end{array}$ \\
\hline $6 / 6^{*}$ & 6 & 217 & 0.279 & 0.8 & 22.39 & 82.3 \\
$6 / 9$ & 1 & 196 & 0.282 & 1.3 & 21.94 & 86.8 \\
$7 / 10^{*}$ & 1 & 166 & 0.217 & 2.1 & 26.53 & 86.2 \\
$7 / 16^{*}$ & 3 & 256 & 0.324 & 0.8 & 24.67 & 77.6 \\
$8 / 19^{*}$ & 5 & 296 & 0.018 & 0.7 & 32.24 & 71.5 \\
$9 / 8$ & 1 & 335 & 0.031 & 0.5 & 25.52 & 72.2 \\
$9 / 14$ & 1 & 332 & 0.006 & 1.4 & 24.03 & 75.0 \\
$6 / 6-9 / 30$ & -- & 319 & 0.129 & 1.1 & 27.15 & 74.8 \\
\hline
\end{tabular}

$324(*)$ - day selected for further hourly analysis due to its higher frequency of extreme value.

325 Note: for the nomenclature of variables please see Fig. 2 and the list of abbreviations and acronyms.

326 The statistical analysis of extreme daily thermal values on cloudy days indicates that when there 327 was a relatively low air temperature, high soil moisture and low wind speed, the EGR could produce 328 a strong daily, daytime and nighttime cooling effect. The analysis also demonstrates that with high 329 air temperature, low soil moisture and wind speed, the EGR had a weak daily cooling effect, or even 330 an obvious daytime warming effect at $30 \mathrm{~cm}$ height (Tables 4, 5). At the same time, the minimum 331 values of $\Delta T_{a_{-}}$daily_nighttime (i.e. the strongest cooling effect) all occurred on cloudy days with 332 relatively low air temperature and wind speed; while cloudy days with relatively low air temperature 333 and high wind speed can produce a weak night-time cooling effect (Tables 4, 5). The analysis of 334 extreme values indicates that the weather scenarios, soil moisture, air temperature, wind speed, 
relative humidity, and the combination of these factors had a strong impact on the daily, day-time and night-time thermal performance of the EGR.

\subsection{EGR hourly thermal performance on selected days under different weather conditions}

Generally, average hourly air temperature differences $\left(\Delta T_{a-}\right.$ hourly) decreased rapidly as the observation height increased. The range of $\Delta T_{a-}$ hourly on sunny days was larger than that on cloudy and rainy days, for example, the average range of $\Delta T_{a \_}$hourly at $30 \mathrm{~cm}$ on selected days was 4.02 , 2.67 , and $0.74^{\circ} \mathrm{C}$, respectively. The duration of the warming effect $\left(\Delta T_{a-}\right.$ hourly $\left.\geq 0{ }^{\circ} \mathrm{C}\right)$ on sunny days was significantly longer than that on cloudy and rainy days as well (Fig. 3). These results imply that the impact of the EGR on $\Delta T_{a-}$ hourly decreases with the increase of observation height, and the magnitude of $\Delta T_{a-}$ hourly varies in the order sunny day> cloudy day> rainy day.

On the four selected sunny days with extreme daily thermal performance, the EGR had a pronounced hourly warming effect during the day and a consistent cooling effect at night. As observation height increased, the amplitude of the hourly daytime warming effect decreased much more than that of the nighttime cooling effect. However, the duration of the hourly warming effect was significantly shorter than that of the cooling effect (Fig. 3). These results, especially the vertical gradient changes of $\Delta T_{a_{-}}$hourly, suggest that the impact of air convection on these measured temperatures was strong. The effect of air convection should be studied in more depth through wind speed observations at different heights. In accordance with a previous study (Solcerova et al., 2017), the lower albedo of the green roof (as indicated by higher values of NR_EGR compared to NR_BR, especially during midday and night, see Fig. 4), together with the special metabolism of sedum (CAM), a relatively thin concrete mortar layer and a good performance of thermal insulation layer of the roof, caused the air above the EGR to warm up more than above the bare roof. Sedum vegetation physiology is an important factor in EGR performance, as, under hot weather conditions, CAM plants, such as sedum, often keep their stomata closed during the day and open them at night (Ting, 1985). This helps the plant to reduce water loss but leads to low daytime evapotranspiration and thus lower daytime cooling (Van Woert et al., 2005; MacIvor and Lundholm, 2011). 


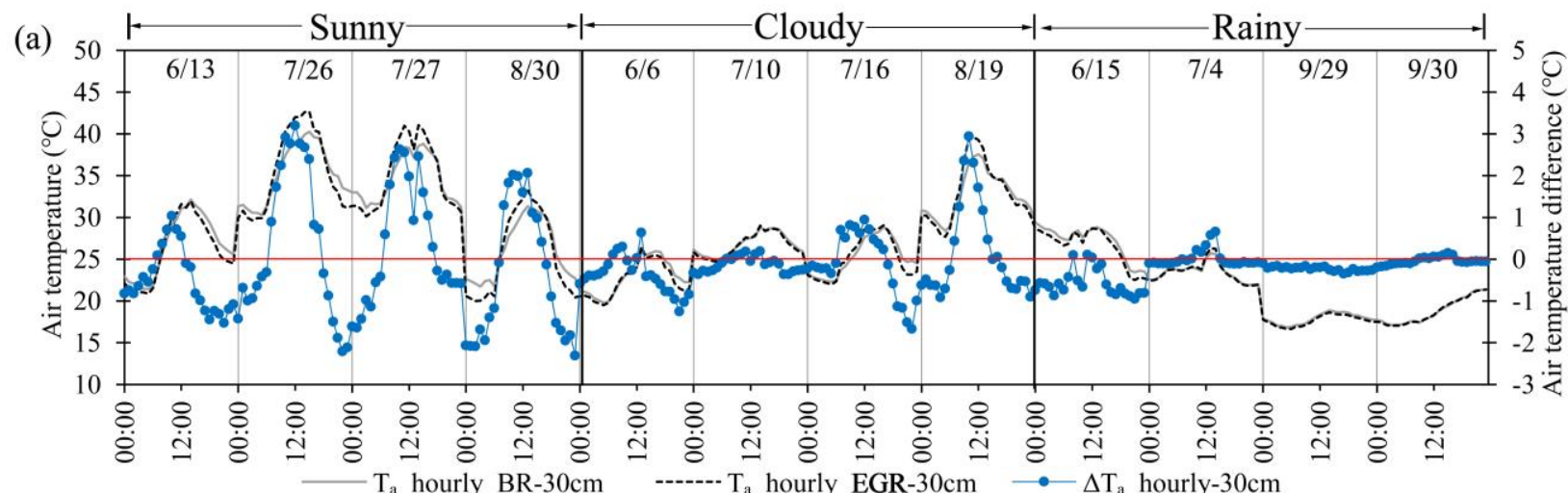

(b)

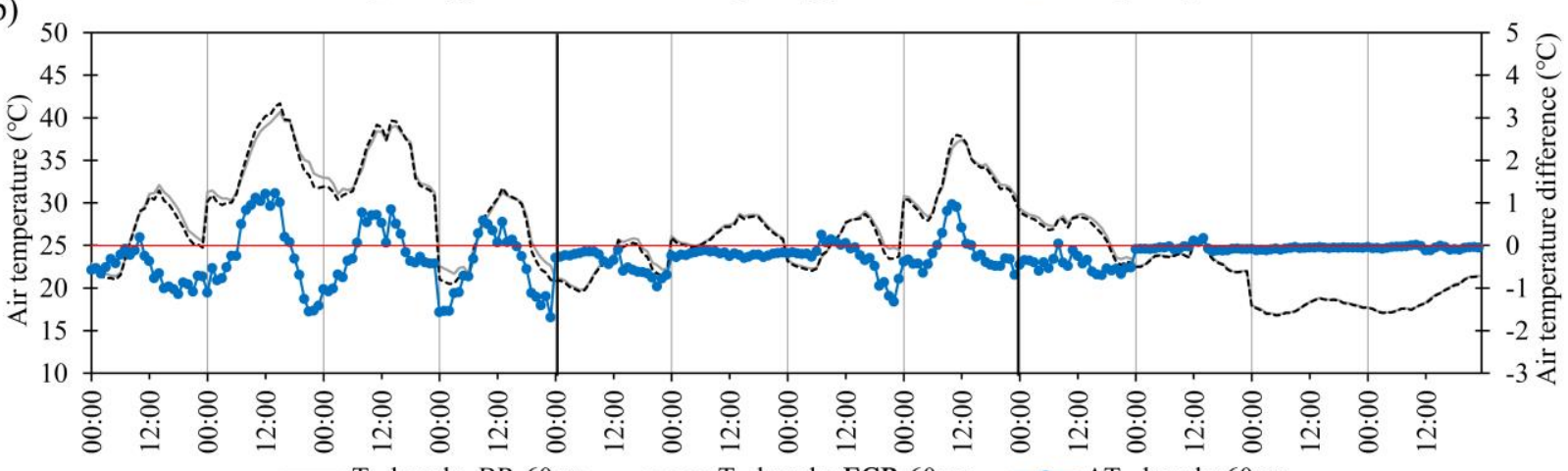

(c)

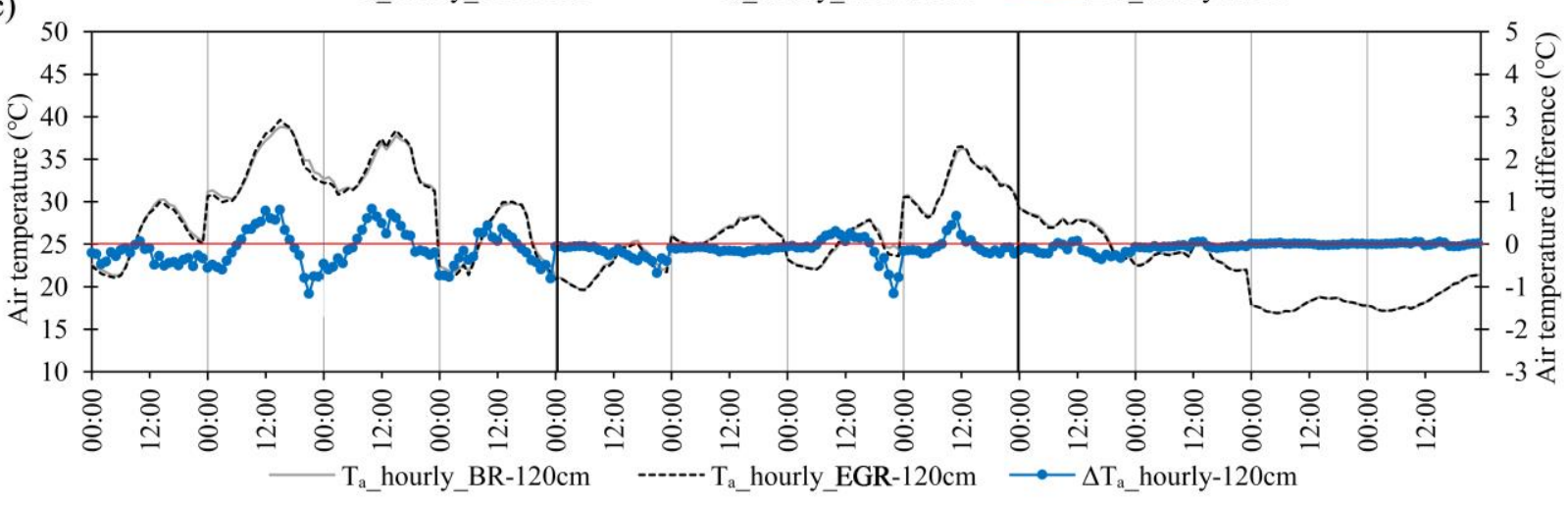

Fig. 3. Hourly air temperature difference $\left(\Delta T_{a_{-}}\right.$hourly) at three observation heights. 


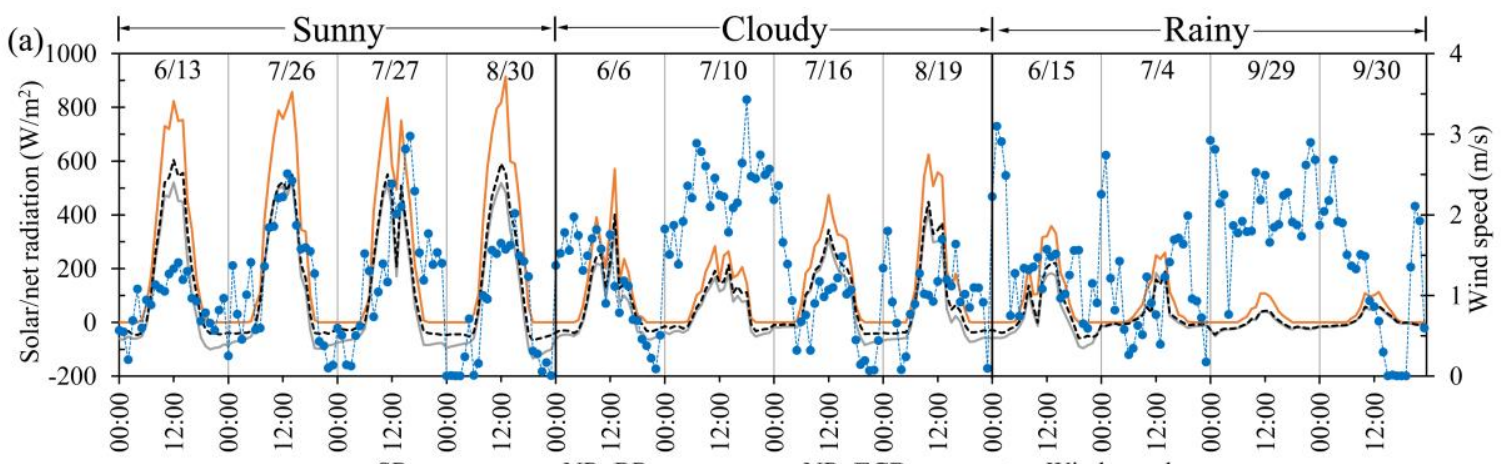

(b)
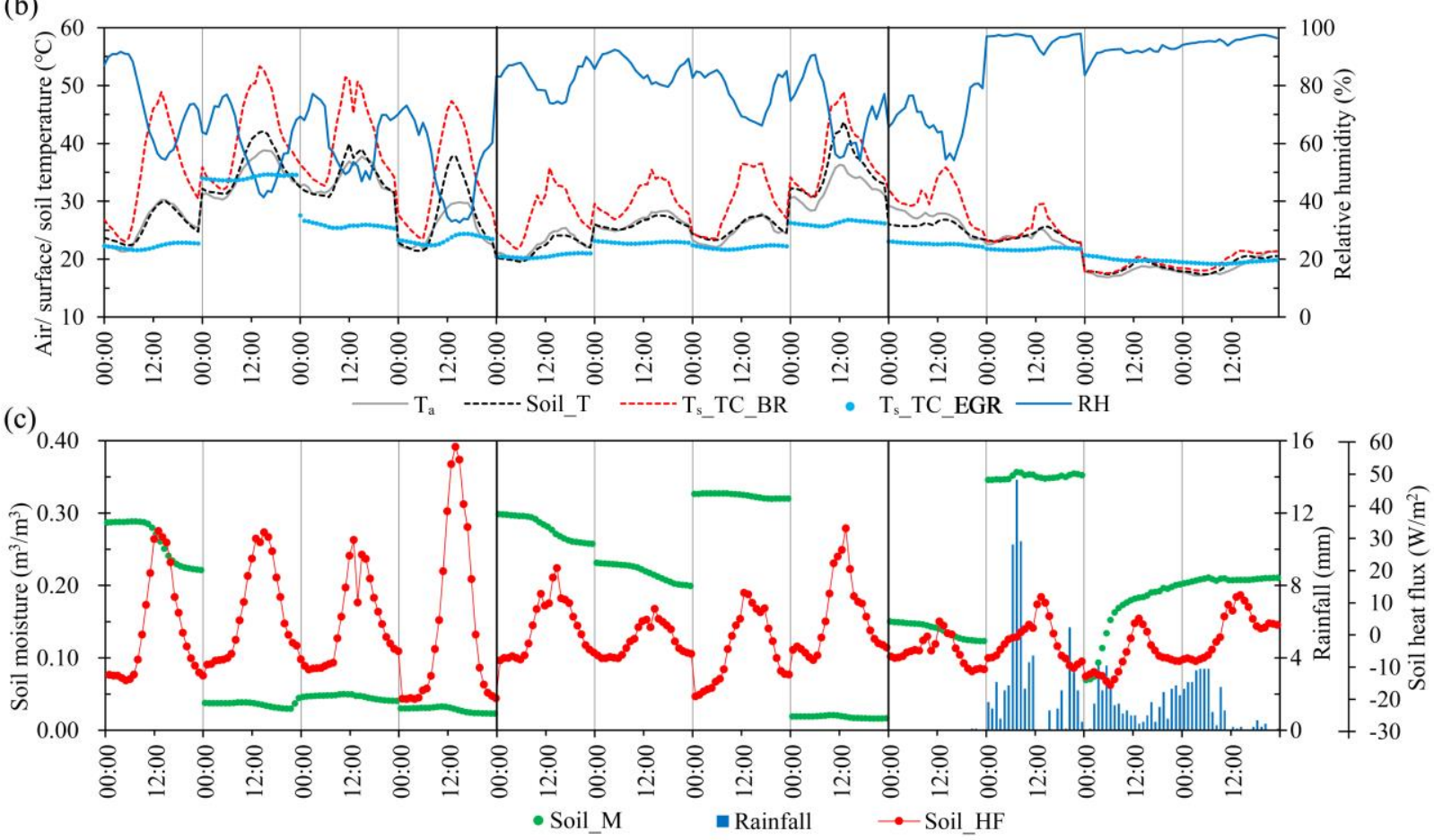

366

Fig. 4. Hourly weather and environmental conditions on the twelve selected days.

Note: the daily data shown in this figure is continuous, but the selected days are not always consecutive; for the nomenclature of all variables please see list of abbreviations and acronyms.

Among the selected sunny days, and only comparing August 30 with July 26 and 27, we find that the heat wave days July 26 and 27 exhibited higher air temperature (the average maximum of the $\Delta T_{a_{-}}$hourly_BR at $120 \mathrm{~cm}$ was $38.28{ }^{\circ} \mathrm{C}$ ) and lower amplitude of soil heat flux, and they also produced, especially at 30cm height, the strongest hourly warming effect (10:00-14:00) and cooling effect (20:00-23:00) (Figs. 3 and 4). These results indicate that on sunny days, air temperature and soil heat flux will have an impact on the EGR thermal performance. In addition, we find that the leaf 
area index (LAI) is different (1.93 on July 26-27 and 2.99 on August 30), which also contributes to the changes in thermal performance of the EGR.

July 26, a sunny day with extreme values, merits special mention. On that day, the EGR was watered at night, which becomes evident by the increase of measured soil moisture (Fig. $4 \mathrm{c}$ ). The watering also caused a significant decrease in surface temperature, soil temperature, and soil heat flux of the EGR (Figs. 4 b, c). This was accompanied by an obvious increase in cooling (the average of $\Delta T_{a-}$ hourly at $30 \mathrm{~cm}$ was $-1.61^{\circ} \mathrm{C}$ ) from $20: 00 \mathrm{~h}$ on 26 July to 04:00 $\mathrm{h}$ July 27 (Fig. 3). In contrast, $\Delta T_{a-}$ hourly during the same time period from July $23-25$ was $-1.25{ }^{\circ} \mathrm{C}$ at $30 \mathrm{~cm}$ height. Under irrigation, the daytime evapotranspiration of substrate increased, while at night, the heat absorbed during the day was release more slowly than from a dry substrate, as shown by the lower amplitude of Soil_HF (Fig. 4 c), contributing to the increased cooling effect. This result implies that irrigation during sunny days with high air temperature and low soil moisture can significantly improve the cooling effect of the EGR.

Among the four cloudy days selected, and especially during 10:00-14:00 h, August 19 exhibited the highest solar radiation, lowest wind speed, and correspondingly highest air, soil and surface temperature, highest soil heat flux, and lowest soil moisture (Fig. 4). Combined, all of these environmental conditions give arise to the highest hourly warming effect of the EGR (Fig. 3). Meanwhile, compared with two of the other cloudy days (June 6 and July 10), during the night-time of July $16(19: 00 \mathrm{~h}-22: 00 \mathrm{~h})$ the EGR created a higher nighttime cooling effect mainly due to very low wind speed (Figs. 3,4). These results imply that except for the possible impact of special metabolism of sedum, the thermal performance of EGRs during cloudy days also depends on solar radiation and wind speed.

During the four selected rainy days, the hourly cooling effect of the EGR was very weak (the average of $\Delta T_{a_{-}}$hourly at $30 \mathrm{~cm}$ was $-0.11^{\circ} \mathrm{C}$ ) for most of the time, but the cooling effect lasted for more than 18 hours. Average hourly air temperature differences $\left(\Delta T_{a_{-}}\right.$hourly) at three observation heights were very small (below $0.85^{\circ} \mathrm{C}$ ) (Figs. 3, 4). These results show that the EGR had a very 
weak effect on outdoor thermal performance on rainy days, but had a cooling effect for most of the time. This is mainly due to the low solar radiation and high soil moisture. Compared to days with heavy rainfall (June 4 and September 29-30), on June 15, the EGR has a much stronger nighttime cooling effect (Fig. 4), indicating that the heavy rainfall weakens the thermal performance of the EGR.

\subsection{Synthesis assessment on EGR thermal performance during summer}

Referring to the above daily, extreme daily, and hourly thermal performance investigation and analysis of the EGR, we selected 14 variables and grouped them into three categories: the difference of thermal and micrometeorological conditions between the EGR and BR (the first seven factors in Table A4), thermal and green biomass properties of EGR (the 8-11 ${ }^{\text {th }}$ factors in Table A4), and the background micrometeorological conditions of the observed site (the last three factors in Table A4), to further synthetically evaluate the factors which may impact the thermal performance of the EGR by applying the methodology described in Section 2.3.4.

Multiple linear regression analysis shows that the statistically significant variables differed among the specific models, and the rank ordering of variables included in the regression models were different. The variables $\Delta R H, S R, \Delta N R, T_{a}, \Delta S o i l \_T_{s_{-}} T I R, \Delta T_{s_{-}} T C_{-}$substrate, Soil_M_average, Soil_T_average, had a higher chance (four or more times higher) of being included in the daily and hourly regression fitting models at different observation heights, and the normalization coefficient of most of them in each corresponding model was also relatively large (Table 6). The results suggest that these factors generally had an important impact on the thermal performance of the EGR $\left(\Delta T_{a}\right)$.

In comparison, substantially more variables were selected in the hourly fitting models than in the daily models (9-13 vs. 4-7) (Table 6). The daily-averaged variables primarily represent the daily variation in the measured factors and their weak, short-term fluctuation. For example, wind speed (WS) was not included in the daily average fitting models at three heights, but was selected in the hourly average fitting models at 30 and $60 \mathrm{~cm}$ height, because the overall daily variation in wind speed was relatively small, but the hourly changes were relatively large (Fig. 4). 
Table 6 Results of the multi-variate linear stepwise regression.

\begin{tabular}{|c|c|c|c|c|c|c|}
\hline \multirow[t]{2}{*}{ Model } & & \multicolumn{2}{|c|}{$\begin{array}{c}\text { Unstandardized } \\
\text { Coefficients }\end{array}$} & \multirow{2}{*}{$\begin{array}{c}\begin{array}{c}\text { Standardized } \\
\text { Coefficients }\end{array} \\
\text { Beta }\end{array}$} & \multirow[t]{2}{*}{$\mathrm{t}$} & \multirow[t]{2}{*}{ Sig. } \\
\hline & & $\mathrm{B}$ & Std. Error & & & \\
\hline Dependent Variable: & (Constant) & -0.042 & 0.023 & -- & -1.825 & 0.041 \\
\hline$\Delta T_{a \_d a i l y-30 \mathrm{~cm}}$ & $\Delta R H-30 \mathrm{~cm}$ & -0.150 & 0.009 & -0.695 & -15.799 & 0.000 \\
\hline \multirow[t]{3}{*}{ Adjusted $R^{2}=0.864$} & $S R$ & 0.001 & 0.000 & 0.495 & 6.034 & 0.000 \\
\hline & $\Delta N R$ & -0.005 & 0.001 & -0.453 & -5.184 & 0.000 \\
\hline & Soil_M_average & -0.477 & 0.068 & -0.275 & -7.002 & 0.000 \\
\hline Dependent Variable: & (Constant) & -0.006 & 0.012 & -- & -0.458 & 0.048 \\
\hline$\Delta T_{a \_ \text {daily }-60 \mathrm{~cm}}$ & $\Delta R H-60 \mathrm{~cm}$ & -0.166 & 0.010 & -0.794 & -17.183 & 0.000 \\
\hline \multirow[t]{3}{*}{ Adjusted $R^{2}=0.888$} & $\Delta N R$ & -0.006 & 0.001 & -0.721 & -9.403 & 0.000 \\
\hline & $\Delta$ Soil_t$T_{s_{-}} T I R$ & -0.013 & 0.003 & -0.324 & -4.563 & 0.000 \\
\hline & $S R$ & 0.000 & 0.000 & 0.285 & 3.818 & 0.000 \\
\hline Dependent Variable: & (Constant) & 0.204 & 0.038 & -- & 5.413 & 0.000 \\
\hline$\Delta T_{a \_d a i l y-120 \mathrm{~cm}}$ & $\Delta T_{s_{-}} T C_{-}$substrate & 0.093 & 0.013 & 3.244 & 7.135 & 0.000 \\
\hline \multirow[t]{6}{*}{ Adjusted $R^{2}=0.767$} & $\Delta T_{s_{-}} T C$ & -0.073 & 0.014 & -2.571 & -5.225 & 0.000 \\
\hline & $T_{a}$ & -0.018 & 0.004 & -1.073 & -4.335 & 0.000 \\
\hline & $\Delta R H-120 \mathrm{~cm}$ & -0.101 & 0.013 & -0.615 & -7.775 & 0.000 \\
\hline & $S R$ & 0.000 & 0.000 & 0.524 & 4.970 & 0.000 \\
\hline & Soil_M_average & -0.282 & 0.043 & -0.476 & -6.540 & 0.000 \\
\hline & Soil_T_average & 0.007 & 0.004 & 0.470 & 1.940 & 0.045 \\
\hline Dependent Variable: & (Constant) & 0.172 & 0.030 & -- & 5.727 & 0.000 \\
\hline$\Delta T_{a \_}$hourly $-30 \mathrm{~cm}$ & $\Delta$ Soil_T $T_{-} \_T I R$ & -0.145 & 0.004 & -0.850 & -32.743 & 0.000 \\
\hline \multirow[t]{12}{*}{ Adjusted $\mathrm{R}^{2}=0.970$} & Soil_T_average & 0.122 & 0.004 & 0.793 & 31.393 & 0.000 \\
\hline & $T_{a}$ & -0.130 & 0.004 & -0.712 & -32.217 & 0.000 \\
\hline & $\Delta T_{s_{-}} T I R$ & 0.123 & 0.005 & 0.546 & 23.448 & 0.000 \\
\hline & $\Delta T_{s_{-}} T C_{-}$substrate & 0.091 & 0.006 & 0.395 & 16.336 & 0.000 \\
\hline & $\Delta R H-30 \mathrm{~cm}$ & -0.116 & 0.003 & -0.394 & -33.319 & 0.000 \\
\hline & $S R$ & 0.001 & 0.000 & 0.228 & 17.988 & 0.000 \\
\hline & $\Delta T_{s_{-}} T C$ & -0.055 & 0.005 & -0.227 & -10.271 & 0.000 \\
\hline & $\Delta N R$ & -0.004 & 0.000 & -0.123 & -13.186 & 0.000 \\
\hline & Soil_HF_average & -0.006 & 0.000 & -0.123 & -13.215 & 0.000 \\
\hline & Soil_M_average & -0.275 & 0.032 & -0.036 & -8.673 & 0.000 \\
\hline & $W S$ & 0.014 & 0.003 & 0.032 & 5.148 & 0.000 \\
\hline & $\Delta S R \_d o w n$ & 0.001 & 0.000 & 0.014 & 3.146 & 0.002 \\
\hline Dependent Variable: & (Constant) & 0.001 & 0.021 & -- & 0.025 & 0.098 \\
\hline$\Delta T_{a \_}$hourly- $60 \mathrm{~cm}$ & $\Delta$ Soil_T $T_{s_{-}} T I R$ & -0.054 & 0.003 & -0.719 & -21.187 & 0.000 \\
\hline Adjusted $\mathrm{R}^{2}=0.925$ & Soil_T_average & 0.038 & 0.002 & 0.559 & 16.828 & 0.000 \\
\hline
\end{tabular}




\begin{tabular}{|c|c|c|c|c|c|c|}
\hline & $\Delta R H-60 \mathrm{~cm}$ & -0.164 & 0.003 & -0.498 & -53.633 & 0.000 \\
\hline & $\Delta T_{s_{-}} T I R$ & 0.048 & 0.003 & 0.480 & 14.697 & 0.000 \\
\hline & $T_{a}$ & -0.038 & 0.003 & -0.471 & -14.956 & 0.000 \\
\hline & $\Delta T_{s \_} T C_{-}$substrate & 0.042 & 0.004 & 0.411 & 10.830 & 0.000 \\
\hline & $\Delta T_{s_{-}} T C$ & -0.029 & 0.004 & -0.271 & -7.726 & 0.000 \\
\hline & $\Delta N R$ & -0.004 & 0.000 & -0.249 & -17.664 & 0.000 \\
\hline & $S R$ & 0.000 & 0.000 & 0.190 & 9.623 & 0.000 \\
\hline & Soil_HF_average & -0.002 & 0.000 & -0.097 & -6.929 & 0.000 \\
\hline & $W S$ & 0.012 & 0.003 & 0.027 & 4.539 & 0.000 \\
\hline & Soil_M_average & -0.064 & 0.022 & -0.019 & -2.935 & 0.003 \\
\hline \multirow{10}{*}{$\begin{array}{l}\text { Dependent Variable: } \\
\Delta T_{a \_} \text {hourly }-120 \mathrm{~cm} \\
\text { Adjusted } \mathrm{R}^{2}=0.858\end{array}$} & (Constant) & 0.501 & 0.015 & -- & 32.488 & 0.000 \\
\hline & $T_{a}$ & -0.036 & 0.002 & -0.875 & -21.559 & 0.000 \\
\hline & $\Delta R H-120 \mathrm{~cm}$ & -0.193 & 0.003 & -0.771 & -71.920 & 0.000 \\
\hline & $\Delta S o i l \_T_{S_{-}} T I R$ & -0.024 & 0.002 & -0.630 & -14.139 & 0.000 \\
\hline & $\Delta T_{s_{-}} T C_{-}$substrate & 0.028 & 0.003 & 0.540 & 10.384 & 0.000 \\
\hline & Soil_T_average & 0.014 & 0.002 & 0.390 & 8.630 & 0.000 \\
\hline & Soil_M_average & -0.452 & 0.016 & -0.265 & -29.102 & 0.000 \\
\hline & $\Delta N R$ & -0.001 & 0.000 & -0.179 & -8.630 & 0.000 \\
\hline & $S R$ & 0.000 & 0.000 & 0.057 & 2.083 & 0.037 \\
\hline & $\Delta S R \_d o w n$ & 0.001 & 0.000 & 0.071 & 7.204 & 0.000 \\
\hline
\end{tabular}

All of other variables, except $L A I$ average, were selected at least once. This finding indicates 431 that differences in the thermal properties, with the exception of $L A I$, between the EGR and BR and 432 the background micro-meteorological conditions had a particularly strong and significant impact on 433 the outdoor air temperature difference $\left(\Delta T_{a}\right)$. However, in this research, LAI is not significantly 434 sensitive to the EGR's thermal performance. It should be noted we only had six LAI observations, 435 and this may not be sufficient to characterize the changes in vegetation biomass. Another possible 436 explanation derives from the special characteristics of the vegetation (Sedum lineare). In the middle 437 of a hot summer day, transpiration of sedum is significantly inhibited to control moisture loss. Thus, 438 the isolation from solar radiation by masking and shading becomes the main factor of the green roof 439 cooling effect.

\section{Discussion}

441 The development of green roofs is an efficient, cost-effective, and sustainable strategy to 
442

443

444

445

446

447

448

449

450

451

452

contribute to reducing the energy needed to cool buildings and mitigate climate change through improved thermoregulation (MacIvor et al., 2016). Currently, green roofs are a widely accepted form of green infrastructure. Their technology has been gradually improved and established, and the cost of EGR solutions is competitive compared to many other types of roofing (Carter and Fowler, 2008). Although a few countries such as Germany, USA, Canada, Australia, Singapore, and Japan have strong initiatives to install green roofs, in many other countries this form of roofing has not yet seen such a widespread use. In part, this may be related to different, and not always consistent, outcomes presented by researchers, mainly due to the significant variations in roof structures and materials tested, as well as the climatic conditions under which the tests take place (Yang et al., 2015). A more important reason might be the constrains from cost, technology and material, as well as the lack of relevant laws and regulations (Carter and Fowler, 2008). For similar reasons, research and applications of green roofs in China started relatively late, and most of the studies to date have focused on the energy saving and thermal balance (Feng et al., 2000; Xiao et al., 2014; He et al., 2016). In this research, we first characterized the outdoor thermal performance of an EGR in Nanjing, China, during a whole summer in three observation heights and then found the reason for the spatiotemporal difference in thermal performance. The results and conclusions obtained through such an experimental case study contribute valuable information on how to design and construct an EGR to optimize cooling effects, especially in a subtropical monsoon climate.

We found that the sedum-covered EGR we tested might not always have a cooling effect during the day. We measured a significant warming effect on 89,27 and 31 days at 30,60 and $120 \mathrm{~cm}$ height, respectively during the observed 117 days. The observed warming effect on sunny days was also found in previous studies (e.g., Wong et al., 2007; Heusinger and Weber, 2015; Solcerova et al., 2017; Peng et al., 2019). Warming was mainly attributed to air convection, different albedo, or the special metabolism of sedum. Here, the nocturnal cooling effect was found larger than that in previous research (e.g., Peng and Jim, 2015; Solcerova et al., 2017), which could be attributed to differences in weather conditions and characteristics of the EGR (Coutts et al., 2013; Lin et al., 2013; Solcerova 
et al., 2017).

It is also important to consider the specific weather and management factors that affected thermal performance of the EGR in this study. Although sedum species have unique physiological characteristics helping to reduce water loss, many leaves of sedum plants were wilting and drying during the first long duration heat wave in 2016 (July 20-August 02, 14 days), and as a result, the LAI decreased from 3.29 to 1.91. Correspondingly, irrigation is essential during summer heat wave events in Nanjing. Irrigation can decrease $\Delta T_{a}$ at night (minimum $\Delta T_{a}$ on July $26(22: 00)$ was $2.21{ }^{\circ} \mathrm{C}$, and on July $25(21: 00)$ was $\left.-1.82{ }^{\circ} \mathrm{C}\right)$. Furthermore, the study results demonstrate that sporadic weather events, particularly heat waves, may require specific management interventions such as irrigation, which may have effects on the long-term outdoor thermal performance of green roofs.

Our exploratory analysis of the thermal performance of the EGR was undertaken by analyzing various collected data. From this analysis, some limitations of the current study and future research needs can be highlighted. Firstly, the coverage and green mass of the EGR changed with microclimate conditions and exhibited spatial heterogeneity. This was not explicitly accounted for, because LAI values of only 8 modules were measured at selected 6 days during the 117 days and linearly interpolated for the other days. Meanwhile, the coverage of vegetation decreased from about $90 \%$ to $75 \%$ during the first heat wave, which could have also affected the thermal performance of the EGR. Further research is needed to fully understand the influence of green plant biomass and its spatial heterogeneity on EGR thermal performance. Secondly, plastic modules and maintenance passageway (i.e., bare roof) also have positive influence on $\Delta T_{a}$. They can raise the warming effect on sunny days and reduce the cooling effect at night. Assessing such marginal impact also requires a more in-depth analysis in the future studies.

\section{Conclusions}

Our study results showed that in subtropical monsoon-climate, the EGR tested had an overall slight daily cooling effect throughout the summer at the three observation heights. The daily cooling 
effect of the EGR was more pronounced at $60 \mathrm{~cm}$ height than that at either 30 or $120 \mathrm{~cm}$. In the daily and hourly temporal scale, our results showed that the sedum-covered EGR had a significant and intermittent warming effect during the day on some sunny days and a pronounced and consistent cooling effect at night.

Under three weather scenarios, our study found the magnitude of $\Delta T_{a_{-}}$daily or $\Delta T_{a_{-}}$hourly varied almost consistently in the order sunny day> cloudy day> rainy day, indicating that the weather has an important impact on the thermal performance of the EGR due to changes in solar/net radiation, air/surface/soil temperature, soil moisture and heat flux, wind speed and relative humidity. Air temperature and soil moisture are the two most influential factors, and in combination produced many extreme daily thermal effects. Generally, the EGR can produce a stronger overall daily and daytime cooling effect on sunny, summer days with relatively low air temperature and high soil moisture, and a stronger nighttime cooling effect on sunny days with low air temperature and low soil moisture.

Our synthesis assessment of the EGR thermal performance indicates that among the 14 selected variables, the difference of relative humidity $(\Delta R H)$, net radiation $(\Delta N R)$, temperature difference between average soil temperature of EGR and surface temperature of BR $\left(\Delta S o i l_{-} T_{s_{-}} T I R\right)$, surface temperature difference between substrate layer of the EGR and BR $\left(\Delta T_{s_{-}} T C_{-}\right.$substrate $)$, solar radiation $(S R)$, ambient air temperature $\left(T_{a}\right)$, average soil moisture (Soil_M_average), average soil temperature (Soil_T_average), and weed speed (WS), strongly affected the cooling effect in different fitting models. Thus, the results imply that the components of the EGR, such as green vegetation (shading, reflection of solar radiation, and evapotranspiration), the soil substrate layer (soil moisture and temperature), and microclimate (wind speed, air temperature, relative humidity etc.) created by the EGR feed back and contribute to the thermal performance of the EGR. These findings can be very valuable to guide EGRs planning and design to improve the outdoor thermal environment and mitigate the UHI effect in a subtropical monsoon climate. 


\section{Acknowledgement}

520 The research was supported by the Key Project on Intergovernmental International Science, 521 Technology and Innovation (STI) Cooperation of China's National Key R\&D Programme (No. 522 2017YFE0196000), and the National Natural Science Foundation of China (Nos. 51878328, 523 31670470, 51478217). The authors thank Jiayu Chen, Junsheng Li, Hailong Xu, Wenbin Xu, 524 Baogang Shi and all other members who helped to conduct the field surveys.

525 


\section{Appendix}
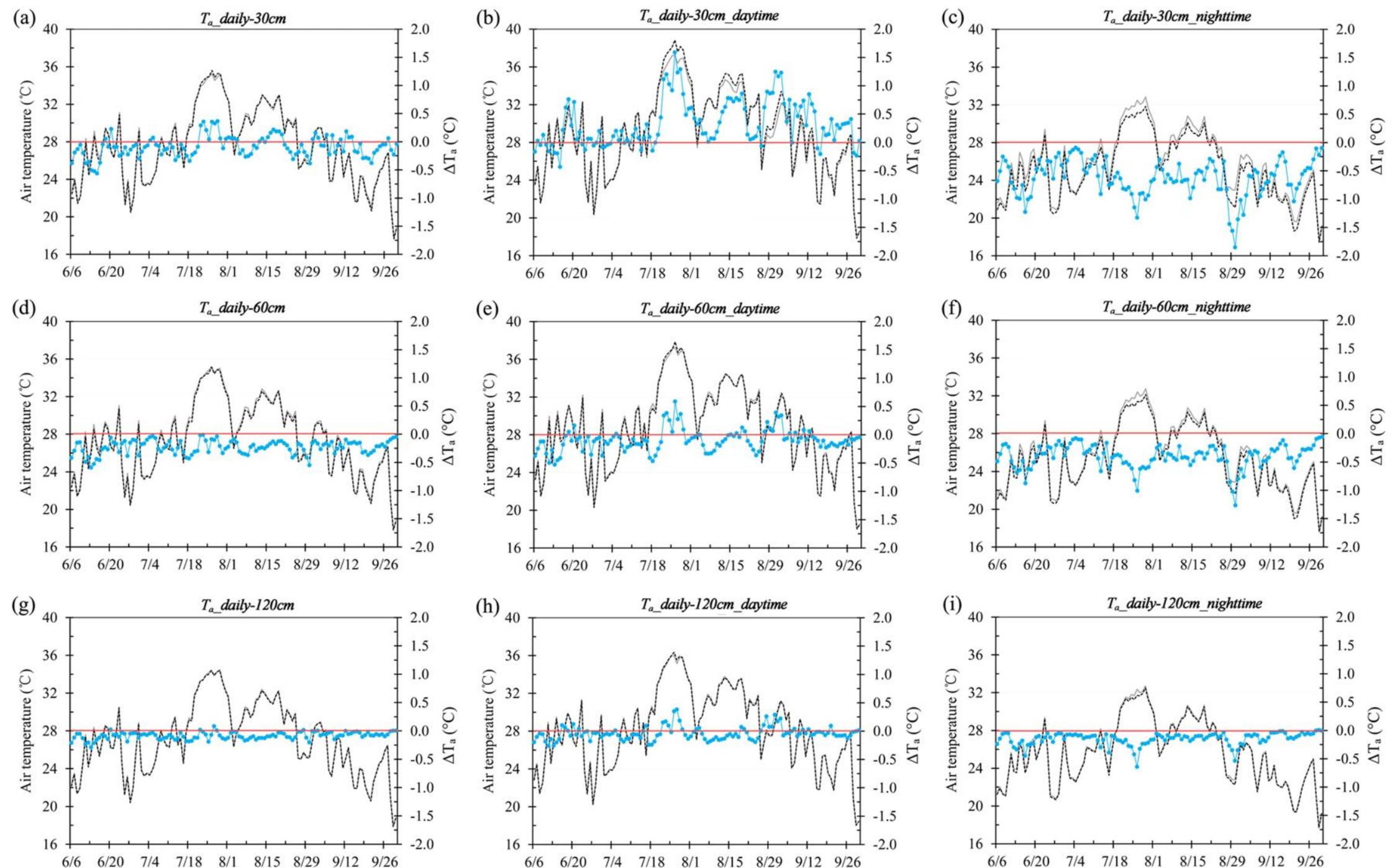
$-T_{a \_}$daily_BR $\quad \cdots \cdots T_{a \_}$daily_EGR $\quad-\Delta \mathrm{T}_{\mathrm{a}}\left({ }^{\circ} \mathrm{C}\right)$

Fig. A1. The daily, day-time and night-time average air temperature difference between bare and green roofs at three observation heights. 


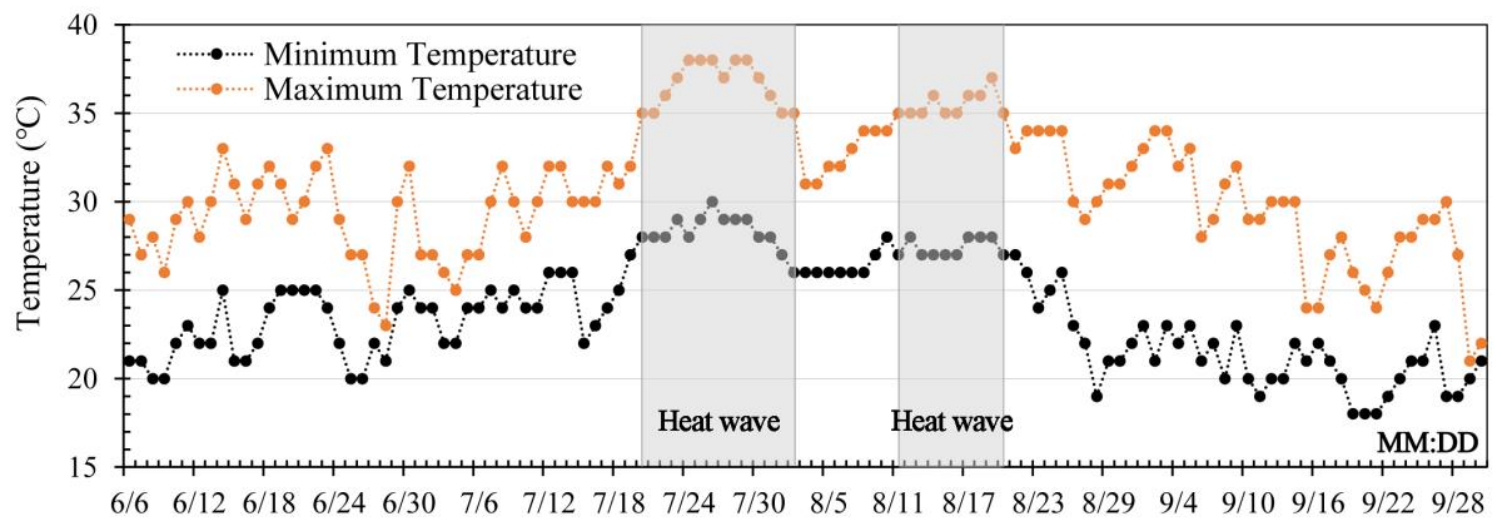

530 Fig. A2. Maximum and minimum daily air temperature of Nanjing between June 6 and September 30, 2016 
Table A1 Summary of the daily thermal performance of EGR $\left(\Delta T_{a \_}\right.$daily $)$at three observation heights.

\begin{tabular}{|c|c|c|c|c|c|c|c|c|c|}
\hline \multirow[b]{2}{*}{ Height and day/night-time } & \multicolumn{4}{|c|}{$\Delta T_{a \_}$daily $<0{ }^{\circ} \mathrm{C}$} & \multicolumn{2}{|c|}{$\Delta T_{a_{\_}}$daily $\geq 0{ }^{\circ} \mathrm{C}$} & \multicolumn{3}{|r|}{ Total } \\
\hline & $\begin{array}{l}\text { Number } \\
\text { of days }\end{array}$ & $\begin{array}{r}\text { Average of } \\
\Delta T_{a \_} \text {daily }\end{array}$ & $\begin{array}{r}\text { Minimum of } \\
\Delta T_{a \_} \text {daily }\end{array}$ & $\begin{array}{l}\text { Number } \\
\text { of days }\end{array}$ & $\begin{array}{r}\text { Average of } \\
\Delta T_{a \_} \text {daily }\end{array}$ & $\begin{array}{l}\text { Maximum of } \\
\qquad \Delta T_{a \_ \text {daily }}\end{array}$ & $\begin{array}{l}\text { Average of } \\
\Delta T_{a \_} \text {daily }\end{array}$ & $\begin{array}{c}\text { Range of } \\
\Delta T_{a \_d a i l y}\end{array}$ & $\begin{array}{l}\text { Standard deviation } \\
\text { of } \Delta T_{a \_ \text {daily }}\end{array}$ \\
\hline$\Delta T_{a \_}$daily $-30 \mathrm{~cm}$ & 82 & -0.19 & -0.56 & 35 & 0.13 & 0.37 & -0.09 & 0.93 & 0.19 \\
\hline$\Delta T_{a \_d a i l y}-30 c m \_d a y t i m e$ & 28 & -0.11 & -0.43 & 89 & 0.47 & 1.59 & 0.32 & 2.02 & 0.41 \\
\hline$\Delta T_{a \_d a i l y}-30 c m \_n i g h t t i m e$ & & -0.63 & -1.85 & 0 & -- & -- & -0.63 & 1.83 & 0.32 \\
\hline$\Delta T_{a \_}$daily $-60 \mathrm{~cm}$ & 117 & -0.23 & -0.59 & 0 & -- & -- & -0.23 & 0.58 & 0.12 \\
\hline$\Delta T_{a \_ \text {daily }}-60 \mathrm{~cm} \_$daytime & 90 & -0.17 & -0.53 & 27 & 0.17 & 0.17 & -0.11 & 1.12 & 0.20 \\
\hline$\Delta T_{a \_d a i l y}$-60cm_nighttime & 117 & -0.40 & -1.27 & 0 & -- & -- & -0.40 & 1.26 & 0.21 \\
\hline$\Delta T_{a \_d a i l y}-120 \mathrm{~cm}$ & 109 & -0.09 & -0.29 & 8 & 0.02 & 0.08 & -0.09 & 0.37 & 0.06 \\
\hline$\Delta T_{a \_}$daily $-120 c m \_d a y t i m e$ & 86 & -0.09 & -0.26 & 31 & 0.11 & 0.38 & -0.04 & 0.64 & 0.12 \\
\hline$\Delta T_{a \_d a i l y}-120 c m \_n i g h t t i m e$ & 116 & -0.15 & -0.64 & 1 & 0.01 & 0.01 & -0.15 & 0.65 & 0.11 \\
\hline
\end{tabular}

534

Table A2 Summary of the daily thermal performance of the EGR $\left(\Delta T_{a \_}\right.$daily $\left.<0^{\circ} \mathrm{C}\right)$ under three weather scenarios (sunny, cloudy, and rainy).

\begin{tabular}{|c|c|c|c|c|c|c|c|c|c|}
\hline \multirow{2}{*}{$\begin{array}{l}\text { Weather scenarios } \\
\text { Height and day/night-time }\end{array}$} & \multicolumn{4}{|c|}{ Sunny } & \multicolumn{3}{|c|}{ Cloudy } & \multicolumn{2}{|r|}{ Rainy } \\
\hline & $\begin{array}{l}\text { Number } \\
\text { of days }\end{array}$ & $\begin{array}{l}\text { Average of } \\
\Delta T_{a \_ \text {daily }}\end{array}$ & $\begin{array}{r}\text { Minimum of } \\
\Delta T_{a \_} \text {daily }\end{array}$ & $\begin{array}{r}\text { Number } \\
\text { of days }\end{array}$ & $\begin{array}{l}\text { Average of } \\
\Delta T_{a \_ \text {daily }}\end{array}$ & $\begin{array}{r}\text { Minimum of } \\
\Delta T_{a \_} \text {daily }\end{array}$ & $\begin{array}{l}\text { Number } \\
\text { of days }\end{array}$ & $\begin{array}{l}\text { Average of } \\
\Delta T_{a \_ \text {daily }}\end{array}$ & $\begin{array}{r}\text { Minimum of } \\
\Delta T_{a \_} \text {daily }\end{array}$ \\
\hline$\Delta T_{a \_d a i l y}-30 \mathrm{~cm}$ & 33 & -0.22 & -0.52 & 18 & -0.16 & -0.38 & 31 & -0.16 & -0.56 \\
\hline$\Delta T_{a \_ \text {daily }-30 c m \_ \text {daytime }}$ & 7 & -0.12 & -0.19 & 4 & -0.05 & -0.16 & 17 & -0.11 & -0.43 \\
\hline$\Delta T_{a \_}$daily $-30 c m \_n i g h t t i m e$ & 56 & -0.83 & -1.85 & 22 & -0.56 & -0.95 & 39 & -0.36 & -0.91 \\
\hline$\Delta T_{a \_}$daily $-60 \mathrm{~cm}$ & 56 & -0.27 & -0.59 & 22 & -0.24 & -0.42 & 39 & -0.17 & -0.44 \\
\hline$\Delta T_{a \_}$daily $-60 c m \_$daytime & 36 & -0.21 & -0.53 & 20 & -0.17 & -0.37 & 34 & -0.14 & -0.41 \\
\hline$\Delta T_{a \_d a i l y}-60 c m \_$nighttime & 56 & -0.52 & -1.27 & 22 & -0.37 & -0.60 & 39 & -0.26 & -0.66 \\
\hline$\Delta T_{a \_ \text {daily }-120 \mathrm{~cm}}$ & 51 & -0.11 & -0.29 & 22 & -0.10 & -0.21 & 36 & -0.07 & -0.21 \\
\hline$\Delta T_{a \_}$daily $-120 c m \_d a y t i m e$ & 37 & -0.12 & -0.26 & 19 & -0.08 & -0.19 & 30 & -0.07 & -0.18 \\
\hline$\Delta T_{a \_ \text {daily }-120 \mathrm{~cm} \_ \text {nighttime }}$ & 56 & -0.04 & -0.64 & 22 & -0.03 & -0.39 & 38 & -0.01 & -0.30 \\
\hline
\end{tabular}


537 Table A3 Summary of the daily thermal performance of the EGR $\left(\Delta T_{a}\right.$ daily $\left.\geq 0{ }^{\circ} \mathrm{C}\right)$ under three weather scenarios (sunny, cloudy, and rainy).

\begin{tabular}{|c|c|c|c|c|c|c|c|c|c|}
\hline \multirow{2}{*}{$\begin{array}{l}\text { Weather scenarios } \\
\text { Height and day/night-time }\end{array}$} & \multicolumn{4}{|c|}{ Sunny } & \multicolumn{3}{|c|}{ Cloudy } & \multicolumn{2}{|r|}{ Rainy } \\
\hline & $\begin{array}{r}\text { Number } \\
\text { of days }\end{array}$ & $\begin{array}{r}\text { Average of } \\
\Delta T_{a_{-} \text {daily }}\end{array}$ & $\begin{array}{r}\text { Maximum of } \\
\qquad \Delta T_{a \_d a i l y}\end{array}$ & $\begin{array}{r}\text { Number } \\
\text { of days }\end{array}$ & $\begin{array}{r}\text { Average of } \\
\Delta T_{a \_d a i l y}\end{array}$ & $\begin{array}{l}\text { Maximum of } \\
\qquad \Delta T_{a \_} \text {daily }\end{array}$ & $\begin{array}{r}\text { Number } \\
\text { of days }\end{array}$ & $\begin{array}{r}\text { Average of } \\
\Delta T_{a \_ \text {daily }}\end{array}$ & $\begin{array}{r}\text { Maximum of } \\
\Delta T_{a \_} \text {daily }\end{array}$ \\
\hline$\Delta T_{a \_}$daily $-30 \mathrm{~cm}$ & 23 & 0.15 & 0.37 & 4 & 0.09 & 0.18 & 8 & 0.09 & 0.23 \\
\hline$\Delta T_{a \_d a i l y}-30 c m \_$daytime & 49 & 0.64 & 1.59 & 18 & 0.32 & 0.86 & 22 & 0.22 & 0.71 \\
\hline$\Delta T_{a \_}$daily $-30 c m \_n i g h t t i m e$ & 0 & -- & -- & 0 & -- & -- & 0 & -- & -- \\
\hline$\Delta T_{a \_}$daily $-60 \mathrm{~cm}$ & 0 & -- & -- & 0 & -- & -- & 0 & -- & -- \\
\hline$\Delta T_{a \_}$daily $-60 \mathrm{~cm} \_$daytime & 20 & 0.20 & 0.59 & 2 & 0.11 & 0.13 & 5 & 0.06 & 0.16 \\
\hline$\Delta T_{a \_}$daily -60cm_nighttime & 0 & -- & -- & 0 & -- & -- & 0 & -- & -- \\
\hline$\Delta T_{a \_ \text {daily }-120 \mathrm{~cm}}$ & 5 & 0.02 & 0.08 & 0 & -- & -- & 3 & 0.01 & 0.03 \\
\hline$\Delta T_{a \_}$daily $-120 c m \_d a y t i m e$ & 19 & 0.15 & 0.38 & 3 & 0.06 & 0.13 & 9 & 0.03 & 0.09 \\
\hline$\Delta T_{a \_d a i l y}-120 \mathrm{~cm}$ _nighttime & 0 & -- & -- & 0 & -- & -- & 1 & 0.01 & 0.01 \\
\hline
\end{tabular}


Table A4 Definition and description of the 14 selected variables.

\begin{tabular}{|c|c|c|}
\hline No. & Name of variables & Definition and calculation method (the nomenclature of variables please see Fig. 2) \\
\hline 1 & $\Delta T_{s_{-}} T I R$ & $\begin{array}{l}\text { The difference of surface temperature between the vegetation layer on the EGR } \\
\left(T_{S_{-}} T I R_{-} \text {vegetation }\right) \text { and } \mathrm{BR}\left(T_{s_{-}} T I R_{-} B R\right)\left({ }^{\circ} \mathrm{C}\right) \text {. }\end{array}$ \\
\hline 2 & $\Delta T_{s_{-}} T C$ & $\begin{array}{l}\text { The difference of surface temperature between EGR }\left(T_{s_{-}} T C_{-} E G R\right) \text { and BR } \\
\left(T_{s_{-}} T C_{-} B R\right)\left({ }^{\circ} \mathrm{C}\right) \text {. }\end{array}$ \\
\hline 3 & $\Delta T_{s \_} T C \_s u b s t r a t e$ & $\begin{array}{l}\text { The difference of surface temperature between substrate layer of the EGR } \\
\left(T_{s_{-}} T C_{-} \text {substrate }\right) \text { and BR }\left(T_{s_{-}} T C_{-} B R\right)\left({ }^{\circ} \mathrm{C}\right) \text {. }\end{array}$ \\
\hline 4 & $\Delta S o i l \_T_{s_{-}} T I R$ & $\begin{array}{l}\text { Temperature difference between average soil temperature (Soil_t_average) of the } \\
\text { EGR and surface temperature of BR }\left(T_{s_{-}} T I R \_B R\right)\left({ }^{\circ} \mathrm{C}\right) \text {. }\end{array}$ \\
\hline 5 & $\Delta R H$ & $\begin{array}{l}\text { The difference of } \mathrm{RH} \text { between EGR }\left(R H_{-} E G R\right) \text { and } \mathrm{BR}\left(R H_{-} B R\right) \text { at corresponding } \\
\text { height }(\%) \text {. }\end{array}$ \\
\hline 6 & $\Delta N R$ & $\begin{array}{l}\text { The difference of net radiation between the EGR }\left(N R_{-} E G R\right) \text { and BR }\left(N R_{-} B R\right) \\
\left(\mathrm{W} / \mathrm{m}^{2}\right) \text {. }\end{array}$ \\
\hline 7 & $\Delta S R \_d o w n$ & $\begin{array}{l}\text { The difference of downward solar radiation }\left(S R \_d o w n\right) \text { between the EGR } \\
\left(S R \_d o w n \_E G R\right) \text { and BR }\left(S R \_d o w n \_B R\right)\left(\mathrm{W} / \mathrm{m}^{2}\right) \text {. Note: the record values of } \\
\text { downward solar radiation sensor were all } \geq 0 \mathrm{~W} / \mathrm{m}^{2} \text {. }\end{array}$ \\
\hline 8 & Soil_M_average & The arithmetic average of the four soil moisture $($ Soil_M $)$ values $\left(\mathrm{m}^{3} / \mathrm{m}^{3}\right)$. \\
\hline 9 & Soil_T_average & The arithmetic average of the four soil temperature $($ Soil_T $)$ values $\left({ }^{\circ} \mathrm{C}\right)$. \\
\hline 10 & Soil_HF_average & The arithmetic average of the two soil heat flow (Soil_HF) values $\left(\mathrm{W} / \mathrm{m}^{2}\right)$. \\
\hline 11 & LAI_average & $\begin{array}{l}\text { Average } L A I \text { of the EGR. Note that we used the connection line composed by six } \\
\text { observation LAI values (two at each month) to get the LAI value in the other days. }\end{array}$ \\
\hline 12 & $S R$ & Average hourly or daily upward solar radiation $\left(\mathrm{W} / \mathrm{m}^{2}\right)$. \\
\hline 13 & $W S$ & Average hourly or daily wind speed $(\mathrm{m} / \mathrm{s})$. \\
\hline 14 & $T_{a}$ & $\begin{array}{l}\text { Average hourly or daily air temperature at } 120 \mathrm{~cm} \text { height above the } \mathrm{BR}\left({ }^{\circ} \mathrm{C}\right) \text {. Note: } \\
\text { we used this factor to represent the background air temperature of the site. }\end{array}$ \\
\hline
\end{tabular}




\section{References}

Alexandri E., Jones P. (2008). Temperature decreases in an urban canyon due to green walls and green roofs in diverse climates. Building and Environment, 43(4), 480-493.

Ascione F., Bianco N., De’ Rossi F., Turni G., Vanoli G.P. (2013). Green roofs in European climates. Are effective solutions for the energy savings in air-conditioning? Applied Energy, 104, 845859.

Berardi U., GhaffarianHoseini A., GhaffarianHoseini A. (2014). State-of-the-art analysis of the environmental benefits of green roofs. Applied Energy, 115, 411-428.

Berardi U. (2016). The outdoor microclimate benefits and energy saving resulting from green roofs retrofits. Energy and Buildings, 121, 217-229.

Bevilacqua P., Mazzeo D., Bruno R., Arcuri N. (2016). Experimental investigation of the thermal performances of an extensive green roof in the Mediterranean area. Energy and Buildings, 122, 63-79.

Carpenter C.M.G., Todorov D., Driscoll C. T., Montesdeoca M. (2016). Water quantity and quality response of a green roof to storm events: Experimental and monitoring observations. Environmental Pollution, 218, 664-672.

Carter T., Fowler L. (2008). Establishng green roof infrastructure through environmental policy instruments. Environmental Management, 42, 151-164.

Calliari, E., Staccione, A., \& Mysiak, J. (2019). An assessment framework for climate-proof naturebased solutions. Science of The Total Environment, 656, 691-700.

Coma J., Pérez G., SoléC., Castell A., Cabeza L. F. (2016). Thermal assessment of extensive green roofs as passive tool for energy savings in buildings. Renewable Energy, 85, 1106-1115.

Coutts A. M., Daly E., Beringer J., Tapper N. J. (2013). Assessing practical measures to reduce urban heat: green and cool roofs. Building and Environment, 70, 266-276.

El Bachawati M., Manneh R., Belarbi R., El Zakhem H. (2016). Real-time temperature monitoring for Traditional gravel ballasted and Extensive green roofs: A Lebanese case study. Energy and 
Buildings, 133, 197-205.

569

570

571

572

573

574

575

576

577

578

579

580

581

582

583

584

585

586

587

588

589

590

591

592

593

Feng C., Meng Q. L., Zhang Y. F. (2010). Theoretical and experimental analysis of the energy balance of extensive green roofs. Energy and Buildings, 42, 959-965.

Francis R. A., Lorimer J. (2011). Urban reconciliation ecology: the potential of living roofs and walls. Journal of Environmental Management, 92:1429-1437.

He Y., Yu H., Dong N. N., Ye H. (2016). Thermal and energy performance assessment of extensive green roof in summer: A case study of a lightweight building in Shanghai. Energy and Buildings, 127, 762-773.

Heusinger, J., \& Weber, S. (2015). Comparative microclimate and dewfall measurements at an urban green roof versus bitumen roof. Building and Environment, 92, 713-723.

Huang Y., Chen Ch., Tsan Liu W. (2017). Thermal performance of extensive green roofs in a subtropical metropolitan area. Energy and Buildings, https://doi.org/10.1016/j.enbuild. $\underline{2017.10 .039}$

Jim C. Y. (2015). Assessing climate-adaptation effect of extensive tropical green roofs in cities. Landscape and Urban Planning, 138, 54-70.

Jim, C. Y., \& Tsang, S. W. (2011). Biophysical properties and thermal performance of an intensive green roof. Building and Environment, 46(6), 1263-1274.

Kohler M., Schmidt M., Grimme F. W., Laar M., de Assuncao P. V. L., Tavares S. (2002). Green roofs in temperate climates and in the hot-humid tropics-far beyond the aesthetics. Environmental Management and Health, 13(4), 382-391.

Kong F. H., Sun C. F., Liu F. F., Yin H. W., Jiang F., Pu Y. X., Cavan G., Skelhorn C., Middel A., Dronova I. (2016). Energy saving potential of fragmented green spaces due to their temperature regulating ecosystem services in the summer. Applied Energy, 183, 1428-1440.

Kosareo L., Ries R. (2007). Comparative environmental life cycle assessment of green roofs. Building and Environment, 42 (7), 2606-2613.

Li W.C., Yeung K. K. A. (2014). A comprehensive study of green roof performance from 
environmental perspective. International Journal of Sustainable Built Environment, 31, 27-134.

595

596

597

598

599

600

601

602

603

604

605

606

607

608

609

610

611

612

613

614

615

616

617

618

619

Lin B., Yu C., Su A., Lin Y. (2013). Impact of climatic conditions on the thermal effectiveness of an extensive green roof. Building and Environment, 67, 26-33.

MacIvor J.S., Lundholm J. (2011). Performance evaluation of native plants suited to extensive green roof conditions in a maritime climate. Ecological Engineering, 37, 407-417.

MacIvor J.S., Margolis L., Perotto M., Drake J. A. P. (2016). Air temperature cooling by extensive green roofs in Toronto Canada. Ecological Engineering, 95, 36-42.

Niachou A., Papakonstantinou K., Santamouris M., Tsangrassoulis A., Mihalakakou G. (2001). Analysis of the green roof thermal properties and investigation of its energy performance. Energy and Buildings, 33 (7), 719-729.

Olivieri F., Perna C. D., D’Orazio M., Olivieri L., Neila J. (2013). Experimental measurements and numerical model for the summer performance assessment of extensive green roofs in a Mediterranean coastal climate. Energy and Buildings, 63, 1-14.

Ouldboukhitine S. E., Belarbi R., Jaffal I., Trabelsi A. (2011). Assessment of green roof thermal behavior: A coupled heat and mass transfer model. Building and Environment 46, 2624-2631.

Pan H. (2011). The analysis of seasonal transition characteristics in Nanjing in recent 60 years. Journal of the Meteorological Sciences, 31(6), 742-746. (in Chinese)

Parizotto S, Lamberts R. (2011). Investigations of green roof thermal performance in temperature climate: a case study of an experimental building in Florianopolis city, Southern Brazil. Energy and Buildings, 43, 1712-1722.

Peng L.L. H., Jim C. (2015). Seasonal and diurnal thermal performance of a subtropical extensive green roof: the impacts of background weather parameters. Sustainability, 7 (8), 11098-11113.

Peng L.L.H., Yang X. S., He Y. F., Hu Z. Y., Xu T. J., Jiang Z. D., Yao L. Y. (2019). Thermal and energy performance of two distinct green roofs: Temporal pattern and underlying factors in a subtropical climate. Energy and Buildings, 185, 247-258.

Perkins S.E., Alexander L.V., Nairn J. R. (2012). Increasing frequency, intensity and duration of 
observed global heatwaves and warm spells. Geophysical Research Letters, 39 (20), 20714.

621

622

623

624

625

626

627

628

629

630

631

632

633

634

635

636

637

638

639

640

641

642

643

644

645

Rowe D.B. (2011). Green roofs as a means of pollution abatement. Environmental Pollution,159, 2100-2110.

Saadatian O., Sopian K., Salleh E., Lim C.H., Riffat S., Saadatian E., Toudeshki A., Sulaiman M.Y. (2013). A review of energy aspects of green roofs. Renewable and Sustainable Energy Reviews, 23, 155-168.

Santamouris M. (2014). Cooling the cities- a review of reflective and green roof mitigation technologies to fight heat island and improve comfort in urban environments. Solar Energy, $103,682-703$.

Sims A.W., Robinson C. E., Smart C. C., Voogt J. A., Hay G. J., Lundholm J. T., Powers B., O’Carroll D. M. (2016). Retention performance of green roofs in three different climate regions. Journal of Hydrology, 542, 115-124.

Solcerova A., van de Ven F., Wang M., Rijsdijk M., van de Giesen N.. (2017). Do green roofs cool the air? Building and Environment, 111, 249-255.

Standardization Administration of China. (2008). GB/T 21984-2008:Short-range weather forecast.

Susca T., Gaffin S., Dell'Osso G. (2011). Positive effects of vegetation: urban heat island and green roofs. Environmental Pollution, 159 (8-9), 2119-2126.

Takakura T., Kitade S., Goto E. (2000). Cooling effect of greenery cover over a building. Energy and Buildings, 31 (1), 1-6.

Teemusk A., Mander Ü..(2009). Greenroof potential to reduce temperature fluctuations of a roof membrane: a case study from Estonia. Building and Environment, 44, 643-650.

Theodosiou T. G. (2003). Summer period analysis of the performance of a planted roof as a passive cooling technique. Energy and Buildings, 35, 909-917.

Ting I. P. (1985). Crassulacean acid metabolism. Annual Review of Plant Biology, 36, 595-622.

Van Woert N. D., Rowe D. B., Andresen J. A., Rugh C. L., Xiao L. (2005). Watering regime and green roof substrate design affect Sedum plant growth. HortScience, 40 (3), 659-664. 
646 Vijayaraghavan K. (2016). Green roofs: A critical review on the role of components, benefits, 647 limitations and trends. Renewable and Sustainable Energy Reviews, 57, 740-752.

648 Williams N. S. G., Rayner J. P., Raynor K. J. (2010). Green roofs for a wide brown land: opportunities 649 and barriers for rooftop greening in Australia. Urban Forestry and Urban Greening, 9, $245-251$.

650 Wong N., Tan P., Chen Y. (2007). Study of thermal performance of extensive rooftop greenery 651 systems in the tropical climate. Building and Environment, 42 (1), 25-54.

652 Xiao M., Lin Y. L., Han J., Zhang G. Q. (2014). A review of green roof research and development in 653 China. Renewable and Sustainable Energy Reviews, 40, 633-648.

654 Yang J., Yu Q., Gong P. (2008). Quantifying air pollution removal by green roofs in Chicago. 655 Atmospheric Environment, 42, 7266-7273.

656 Yang W. S., Wang Z. Y., Cui J. J., Zhu Z. S., Zhao X. D. (2015). Comparative study of the thermal 657 performance of the novel green (planting) roofs against other existing roofs. Sustainable Cities $658 \quad$ and Society, 16, 1-12. 